\title{
Volcanic hydrothermal systems as potential analogues of Martian sulphate-rich terrains
}

\section{A. Rodríguez* \& M.J. van Bergen}

Department of Earth Sciences, Utrecht University, Budapestlaan 4, 3508 TA, Utrecht, the Netherlands

* Corresponding author. Email: a.rodriguezbadilla@uu.nl

Manuscript received: 30 September 2014, accepted: 16 February 2015

\section{Abstract}

Remote sensing observations and rover missions have documented the presence of sulphate-rich mineral associations on Mars. Many of these minerals are paleo-indicators of hydrous, acidic and oxidising environments that must have prevailed in Mars' distant past, contrary to the present conditions. Furthermore, occurrences of silica together with high $\mathrm{Cl}$ and $\mathrm{Br}$ concentrations in Martian soils and rocks represent fingerprints of chemically atypical fluids involved in processes operating on the surface or at shallow depth. From field observations at representative active volcanoes in subduction settings, supported by geochemical modelling, we demonstrate that volcanic hydrothermal systems are capable of producing Mars-like secondary mineral assemblages near lakes, springs and fumaroles through the action of acidic fluids. Water-gas-rock interactions, together with localised flow paths of water and fumarolic gas emitted from associated subaerial vents, lead to deposition of a range of sulphates, including gypsum, jarosite, alunite, epsomite and silica. Evaporation, vapour separation and fluid mixing in (near-) surface environments with strong gradients in temperature and fluid chemistry further promote the diversity of secondary minerals. The mineralogical and chemical marks are highly variable in space and time, being subject to fluctuations in ambient conditions as well as to changes in the status of volcanic-hydrothermal activity. It is concluded that active processes in modern volcanic-geothermal systems may be akin to those that created several of the sulphate-rich terrains in the early history of Mars.

Keywords: volcanic hydrothermal systems, sulphates, volcanic lakes, Mars surface mineralogy

\section{Introduction}

High concentrations of sulphur, chlorine and bromine found by Viking, Pathfinder and MER (Mars Exploration Rovers 0pportunity and Spirit) in soil and rock weathering rinds indicate that substantial volcanic degassing of volatile-rich magmas probably occurred on Mars throughout time (Gellert et al., 2004, 2006; Haskin et al., 2005). The presence of sulphates at Meridiani Planum, Valles Marineris and Gusev crater suggest that aqueous alteration by low $\mathrm{pH}$ sulphate-rich fluids was involved (Clark et al., 2005; Zolotov \& Mironenko, 2007; Ming et al., 2008). Although none of the SNC (shergottite, nakhlite and chassigny) Martian meteorites are pervasively altered, minor amounts of sulphates and halogens like $\mathrm{Cl}$ and $\mathrm{Br}$ suggest that hydrothermal briny aqueous fluids have interacted with the host rocks and secondary phases formed afterwards upon the evaporation of these solutions (Bridges et al., 2001; Sutton et al.,
2001; Greenwood, 2005). High silica abundances in soils from Meridiani Planum, Gusev crater and in some chasmata of Valles Marineris are most likely a product of intensive acid rock leaching processes and silica precipitation from saturated thermal fluids (Glotch \& Bandfield, 2006; Milliken et al., 2008; Squyres et al., 2008; Weitz et al., 2010; Wendt et al., 2011). These observations suggest that low-pH acid-sulphate weathering was a major alteration pathway at some point during Mars' geological history (Bibring et al., 2006; Ming et al., 2006; Zolotov \& Mironenko, 2007). In contrast to Earth, where the carbon cycle is a major controlling factor in surface geochemistry, it seems that sulphur cycling processes dominated on Mars at least during part of its evolution (Gaillard et al., 2013). Hot and acidic fluids, enriched in sulphur and halogens, are typically encountered on terrestrial volcanoes, and the styles and distribution of mineral alteration at volcanic settings (Africano \& Bernard, 2000; van Hinsberg et al., 2010) have been compared to those inferred for 
Mars (Varekamp, 2008; Hynek et al., 2013; Marcucci et al., 2013; Marcucci \& Hynek, 2014). Even though volcanism has been an important process in shaping Mars' surface, especially during its early geological history (Wilson et al., 2001; Neukum et al., 2004; Dohm et al., 2009; Carr \& Head, 2010), its relevance to the formation of sulphate-rich mineral associations remains to be confirmed. In this paper we explore the possibility that formation conditions of sulphate-rich assemblages, together with $\mathrm{Cl}, \mathrm{Br}$ and $\mathrm{SiO}_{2}$ enrichments on Mars, were similar to those of terrestrial volcanic hydrothermal systems, based on a concise literature review of representative Martian and terrestrial occurrences, and supported by geochemical modelling. The working hypothesis is that volcanic geothermal systems can serve as potential analogues to some of the sulphate-rich terrains on Mars and that both the style and extent of aqueous alteration can be assessed by comparing Martian systems with terrestrial counterparts. Although meteorite impacts could have created transient thermal anomalies in the Mars crust, leading to impact-induced hydrothermal systems that were fed by ice melting or by preexisting subsurface fluids (Abramov \& Kring, 2005; Barnhart et al., 2010), this scenario is not considered here.

\section{Mars observations}

Global mapping using morphological (Tanaka et al., 1992) and spectral (Christensen et al., 2001; Bibring et al., 2005) data has revealed that volcanic products cover vast areas of the Martian surface. Volcanic landforms are not uniformly distributed but are rather concentrated in a few large volcanic provinces located at Tharsis and Elysium Rises (Hodges \& Moore, 1994), around the ancient Hellas impact basin (Williams et al., 2009) and at Syrtis Major (Grott et al., 2013). The oldest volcanic surfaces (ca. 4 to $3.7 \mathrm{Ga}$ ) are mainly present on the highland shields such as Hadriaca and Tyrrhena Montes, northeast from the Hellas impact basin (Grott et al., 2013). Volcanism in the highlands probably terminated around $1 \mathrm{Ga}$ at the latest (Williams et al., 2009). More recent volcanic activity has been limited to Tharsis and Elysium. The youngest lavas in the latter volcanic province were emplaced in the Cerberus plains a few million years ago (Vaucher et al., 2009). Even though only a few Noachian volcanic terrains have been preserved, Martian volcanism was most likely intense during its early history and gradually decreased over time with episodic periods of higher activity (Werner, 2009; Hauber et al., 2011; Robbins et al., 2011; Xiao et al., 2012). Since the sulphur composition of Martian basalts is relatively high (Lodders, 1998; Mc Sween et al., 2006, 2008), the crystallisation of Martian lavas must have released significant amounts of sulphur-rich volatiles. Reaction of volatile sulphur compounds with water in magmatic vapours, ice or groundwater would inevitably produce acidic fluids. Similar to Earth, likely environments for surface discharge of sulphur-rich volcanic fluids are fumaroles, solfataras and hot springs.

\section{Potential volcaniclastic facies}

The sediments analysed by the 0pportunity rover at Eagle crater (Meridiani Planum), which were grouped under the name Burns Formation (ca. 3.7-3.5 Ga), appear to be aeolian, but others exhibit textural features strongly indicative of subaqueous sediment transport (Squyres et al., 2004; Grotzinger et al., 2005; McLennan et al., 2005) or massive weathered ice deposits (Niles $\&$ Michalski, 2009). Some authors have also associated the sediment deposits with base surges from volcanic explosions or impact events (McCollom \& Hynek, 2005; Knauth et al., 2005). The presence of textures such as cross-bedding, lamination, gradation, apparent bomb sag and probably accretionary lapilli suggests that pyroclastic and perhaps hydro-volcanic processes constructed Home Plate, Gusev crater (Squyres et al., 2007; Lewis et al., 2008). Moreover, some layered sediments examined by Mars Global Surveyor (MGS) appear to thin out with increasing distance from the Tharsis region, which suggests that these post-Noachian materials could correspond to volcanic ash flows and air fall deposits from explosive eruptions (Hynek et al., 2003; Broz \& Hauber, 2012).

\section{Sulphate detections}

Sulphides are two to three times more abundant in shergottites than in terrestrial igneous rocks (Lorand et al., 2005), pointing to elevated sulphur concentrations in the interior of Mars. Moreover, surface deposits contain high levels of sulphur $\mathrm{SO}_{3}$ up to $\sim 37 \mathrm{wt} \%$, average $\sim 6 \mathrm{wt} \%$ ) mostly in the form of sulphates (King \& McLennan, 2010). High sulphur concentrations have been detected in soils of the northern plains by Viking (up to $10 \mathrm{wt} \% \mathrm{SO}_{3}$; Clark et al., 1976; Baird et al., 1976; Toulmin et al., 1976) in Ares Vallis by Pathfinder (up to $8 \mathrm{wt} \% \mathrm{SO}_{3}$; Rieder et al., 1997; Bell et al., 2000; Economou, 2001; Foley et al., 2003), in Columbia Hill outcrops (Gusev crater) by MER Spirit and at Meridiani Planum by MER 0pportunity (up to 40 and $25 \mathrm{wt} \% \mathrm{SO}_{3}$, respectively; Gellert et al., 2004, 2006; Rieder et al., 2004; Squyres et al., 2004; Ming et al., 2006; Wang et al., 2006). The main sulphates identified by 0pportunity are jarosite $\left[\left(\mathrm{K}, \mathrm{Na}_{1} \mathrm{H}_{3} \mathrm{O}\right) \mathrm{Fe}_{3}\left(\mathrm{SO}_{4}\right)_{2}(\mathrm{OH})_{6}\right]$ (Klingelhöfer et al., 2004), gypsum and magnesium sulphates (Squyres et al., 2004; Clark et al., 2005; Wang et al., 2006).

Northern polar region Gypsum $\left(\mathrm{CaSO}_{4} \cdot 2 \mathrm{H}_{2} \mathrm{O}\right)$ deposits were identified in the northern polar region dune fields of Olympia Planum using OMEGA data (Langevin et al., 2005; Fishbaugh et al., 2007). Later observations revealed that gypsum deposits are not only restricted to Olympia Planum but are present in various sediments covering the northern polar cap and the circumpolar dune field (Massé et al., 2010). The bulk of the observed gypsum consist of sand-sized grains rather than surficial crusts or fine-grained deposits, which is more consistent with percolation within aeolian deposits (Fishbaugh et al., 2007; Horgan 
et al., 2009; Massé et al., 2010). Gypsum crystals, either preexisting or authigenic, were probably enclosed by ice crystals during formation of the polar cap, and were then released after sublimation of the ice (Massé et al., 2010). Irrespective of the sedimentation mechanisms, gypsum could have formed by the interaction of $\mathrm{Ca}$ (coming from dissolution of Ca-rich phases like pyroxene and plagioclase) with $\mathrm{SO}_{4}$-rich fluids derived either from water-condensed $\mathrm{SO}_{2}$ produced by volcanic activity (Fairén et al., 2004; Tosca et al., 2004) or from weathering of sulphides in the presence of water under oxidative conditions (Chevrier et al., 2004; 2006). Although water, sulphur and calcium may have coexisted locally within the sand grains, massbalance calculations suggest that sulphide oxidation and/or $\mathrm{SO}_{2}$ coming from volcanic activity could have significantly contributed to gypsum formation (Fishbaugh et al., 2007). In view of their Late Amazonian age, the gypsum deposits from the northern polar cap do not easily fit into the global alteration history of Mars, which conveys that sulphate deposition was prominent during the Hesperian (Bibring et al., 2006).

Valles Marineris The OMEGA spectrometer also mapped sulphates in equatorial regions like Valles Marineris (Bibring et al., 2005; Mangold et al., 2008). The interior layered deposit (ILD) terrains, containing the sulphates, represent important deposits, tens of kilometres wide and several kilometres thick (Bibring et al., 2005; Gendrin et al., 2005). Deposition environments proposed for ILD include colluvial (Nedell et al., 1987), aeolian (Peterson, 1981), spring deposits (Rossi et al., 2008), volcanic (Chapman \& Tanaka, 2001; Komatsu et al., 2004) lacustrine (McCauley, 1978; Komatsu et al., 1993, Lucchitta et al., 1994) and explosive subaerial (Lucchitta, 1987, 1990; Chapman, 2002; Hynek et al., 2013) or subglacial volcanic settings (Nedell et al., 1987, Chapman \& Tanaka, 2001; Komatsu et al., 2004). West Candor Chasma (Valles Marineris) is the canyon with the thickest stack of ILD and one of the largest areas covered by sulphates (Mangold et al., 2008; Flahaut et al., 2010, 2012; Fuenten et al., 2014). Sequences of polyhydrated sulphates (Mg-, Fe- and possibly also Ca-rich) and monohydrated sulphates (mostly kieserite, $\mathrm{MgSO}_{4} \cdot \mathrm{H}_{2} \mathrm{O}$ ) have been detected by OMEGA and CRISM in Capri Chasma (Flahaut et al., 2010), 0phir Chasma and Ophir Mensa (Flahaut et al., 2010; Wendt et al., 2011), West Candor Chasma and Candor Mensa (Fuenten et al., 2014). The inferred rather monotonous distribution of these sulphates over wide areas, and intercalation of monohydrated and polyhydrated phases suggests that they may have formed via evaporation of a shallow body of standing water (Flahaut et al., 2010), rain, snow, ice (Niles \& Michalsky, 2009; Weitz et al., 2010; Wendt et al., 2011) or local groundwater (Grindod $\&$ Balme, 2010). Climate change or volcanism possibly promoted the stability of liquid water on Mars' surface (Mangold et al., 2008, Kite et al., 2013). The presence of kieserite in heavily eroded scarps suggests that this phase was probably present in the original rock, where it had formed either during formation and diagenesis of sediments or during hydrothermal alteration at depth (Mangold et al., 2008). Experiments have shown that kieserite is easily converted to hexahydrite $\left(\mathrm{MgSO}_{4} \cdot 6 \mathrm{H}_{2} \mathrm{O}\right)$ and epsomite $\left(\mathrm{MgSO}_{4} \cdot 7 \mathrm{H}_{2} \mathrm{O}\right)$ when exposed to water. In contrast, on renewed desiccation these minerals are not transformed back to kieserite but form amorphous phases (Vaniman et al., 2004). Also, dehydration of polyhydrated sulphates is unlikely to have occurred at any time on the surface of Mars (Roach et al., 2009), therefore kieserite may not have been preserved in deposits that experienced cycles of surface hydration and desiccation. Local associations of amorphous silica and jarosite in Ophir Chasma (Wendt et al., 2011), Iani Chaos (Sefton-Nash et al., 2012), Melas Chasma (Bishop et al., 2009), Juventae Chasma (Milliken et al., 2008; Bishop et al., 2009), Melas Plateau (Weitz et al., 2010) and Noctis Labyrinthus (Thollot et al., 2012) have been interpreted as products of low-temperature acid alteration of basalts.

Meridiani Planum Jarosite, Mg- and Ca-sulphates have been detected in situ by MER Opportunity at Meridiani Planum in the aeolian and subaqueous sedimentary sequence of the Burns Formation (Klingelhöfer et al., 2004; Squyres et al., 2004; Clark et al., 2005; Grotzinger et al., 2005; McLennan et al., 2005, Glotch et al., 2006). Hematite $\left(\mathrm{Fe}_{2} \mathrm{O}_{3}\right)$ nodules in this formation probably formed during early burial diagenesis of the sediments, either by replacement of pre-existing sulphates (Christensen et al., 2004) or by jarosite breakdown (Fernández-Remolar et al., 2005; Sefton-Nash \& Catling, 2008). Fluid-rock modelling by Tosca et al. (2005) suggested that assemblages of Fe-, Mgand $\mathrm{Ca}$-sulphates together with hematite can be derived from low-pH and $\mathrm{SO}_{4}$-rich fluids that have interacted with basalts. Groundwater dissolution of jarosite may have provided $\mathrm{Fe}^{3+}$ for hematite precipitation, but the substantial amounts of jarosite still present would imply that the water-mediated diagenesis did not proceed for long enough to convert all the iron into oxides. Hence, water/rock ratios must have been low, possibly due to water removal via freezing or evaporation (Elwood-Madden et al., 2004; Squyres \& Knoll, 2005).

Gusev and Gale craters The MER Spirit excavated soils exhibit high albedo and relatively white to yellow colours at several locations south of Husband Hill in Gusev crater. Alpha particle $\mathrm{X}$-ray spectrometer (APXS) observations revealed high sulphur contents, up to $35 \mathrm{wt} \% \mathrm{SO}_{3}$ (Johnson et al., 2007). Mössbauer spectrometry suggested that the soils contain $\mathrm{Fe}^{3+}$-bearing sulphates in various states of hydration, such as ferricopiapite $\left[\mathrm{Fe}_{0.67}{ }^{3+} \mathrm{Fe}_{4}{ }^{3+}\left(\mathrm{SO}_{4}\right)_{6}(\mathrm{OH})_{2} \cdot 20\left(\mathrm{H}_{2} \mathrm{O}\right)\right]$, hydronium jarosite $\left[\left(\mathrm{H}_{3} \mathrm{O}\right) \mathrm{Fe}_{3}{ }^{3+}\left(\mathrm{SO}_{4}\right)_{2}(\mathrm{OH})_{6}\right]$, fibroferrite $\left[\mathrm{Fe}^{3+}\left(\mathrm{SO}_{4}\right)(\mathrm{OH}) \cdot 5\left(\mathrm{H}_{2} \mathrm{O}\right)\right]$, rhomboclase $\left[\mathrm{HFe}^{3+}\left(\mathrm{SO}_{4}\right)_{2} \cdot 4\left(\mathrm{H}_{2} \mathrm{O}\right)\right]$ and paracoquimbite $\left[\mathrm{Fe}_{2}{ }^{3+}\left(\mathrm{SO}_{4}\right)_{3} \cdot 9\left(\mathrm{H}_{2} \mathrm{O}\right)\right]$ (Gellert et al., 2006; Morris et al., 2006; Ming et al., 2006; Wang et al., 2006; Johnson et al., 2007). Furthermore, combined Mössbauer and APXS data showed the presence of $\mathrm{Fe}-, \mathrm{Mg}$ - and Ca-sulphates in Paso Robles class soils (Yen et al., 2008). Calcium sulphates in the light-toned salty 
soils suggest that the degree of alteration of local rocks was more severe and went beyond olivine dissolution (Wang et al., 2008). The geochemical and mineralogical observations favour ion transportation by fluids and salt deposition in an open hydrologic system as a plausible scenario for the deposition of sulphates in the subsurface regolith (Wang et al., 2006). Magnesium and iron carbonates in some outcrops of volcaniclastic rocks at Columbia Hill, east of Husband Hill (Carter \& Poulet, 2012), may have formed from low-temperature hydrothermal activity and limited water-rock interaction within a Noachian ephemeral lake in Gusev crater (Ruff et al., 2014).

Gale crater exposes a thick sequence of bedded deposits with an upward transition from phyllosilicate and phyllosilicate/sulphate-bearing layers to predominantly sulphate-bearing layers, possibly reflecting a global shift from near-neutral/alkaline to more acidic conditions (Milliken et al., 2010). CRISM spectra indicate the presence of mono- and polyhydrated magnesium sulphates (Milliken et al., 2010). The sedimentary deposits are probably Early Hesperian in age, and their geological characteristics could be explained by lacustrine and aeolian environments (Thomson et al., 2011; Wray, 2013). After the impact that formed Gale crater, a hydrothermal system may have been active for several hundred thousand years, and a crater lake with associated sediments is likely to have formed (Schwenzer et al., 2012).

Because of its ubiquity, acid-sulphate alteration has been a major feature on Mars' surface, having produced predominantly iron, magnesium and calcium sulphates (Gellert et al., 2004, 2006; Morris et al., 2004, 2006; Tosca \& McLennan et al., 2006; Johnson et al., 2007; Bishop et al., 2009; Ehlmann et al., 2011; Gaillard et al., 2013). The presence of Fe-sulphates implies that environmental conditions were rather oxidising and acidic ( $\mathrm{pH}<4)$ (Nordstrom \& Alpers, 1999; Nordstrom et al., 2000; Bigham \& Nordstrom, 2000). Since the aqueous solubilities of iron and magnesium sulphates are high, the abundances of these minerals point to limited interaction between sulphurrich acidic fluids and ferromagnesian minerals such as olivine and pyroxene. Two scenarios can broadly explain the formation of abundant sulphate on the Martian surface: (1) alteration of sulphide-rich rocks (Fernández-Remolar et al., 2005, Zolotov \& Shock, 2005; Dehouck et al., 2012) and (2) alteration in the presence of $\mathrm{SO}_{2}$ (acid fog or groundwater) (Tosca et al., 2004, 2005; Chevrier \& Mathé, 2007; Zolotov \& Mironenko, 2007).

\section{Silica-rich deposits}

The role of water in the formation of silica-rich deposits on Mars has been somewhat controversial. Evidence for acid leaching have been inferred for Meridiani Planum, where the Mini-TES (Miniature Thermal Emission Spectrometer) of the 0pportunity rover detected as much as $25 \%$ of opaline silica (hydrated amorphous silica) and/or high-silica glass in outcrop rocks associated with sulphates (Glotch et al., 2006). This paragenesis is consistent with aqueous deposition of silica at low $\mathrm{pH}$ (Zolotov \& Mironenko, 2007). A similar association of silica-rich phases (amorphous silica, phyllosilicates or zeolites) and (less abundant) sulphates is present in the western Hellas Basin (Bandfield, 2008). Acid hydrothermal leaching of basaltic rocks has also been proposed as the formation mechanism for opaline silica deposits in the Nili Patera caldera on the Syrtis Mayor volcanic complex (Skok et al., 2010). Additionally, APXS analysis of light-coloured soils by Spirit at Husband Hill (Gusev crater) revealed the combination of elevated $\mathrm{SiO}_{2}$ contents and the presence of Fe and $\mathrm{Mg}$ sulphates at the sites of Paso Robles (Yen et al., 2008) and Tyrone (Wang et al., 2008), indicating that these soils are probably formed by the interaction between rocks and fumarolic condensates derived from degassing magma and/or by oxidative alteration of crustal Fe-sulphide deposits (Yen et al., 2008). Amorphous silica and jarosite associations have also been identified by CRISM data on plateaus above Juventae Chasma (Milliken et al., 2008; Bishop et al., 2009), Melas Chasma (Metz et al., 2009) and Ophir Chasma (Wendt et al., 2011), where they have been interpreted as the product of acid alteration of basalts. Extremely high concentrations of amorphous silica ( $>90 \% \mathrm{SiO}_{2}$ ) have been measured by MER Spirit's APXS in soils next to Home Plate, Gusev crater (Squyres et al., 2008). The silica phase is opal-A, according to thermal infrared spectra acquired by the Mini-TES (Squyres et al., 2008). From a negative correlation between the $\mathrm{SiO}_{2}$ contents and $\mathrm{Fe}^{3+} / \mathrm{Fe}_{\text {tot }}$ values in the soils, the lack of sulphur enrichments and textural evidence, Ruff et al. (2011) concluded that these silica-rich deposits probably formed by precipitation from near-neutral $\mathrm{pH}$ thermal springs or geysers.

\section{Chlorine and bromine abundances}

Both Martian basalts (meteorites and surface basalts) and the bulk Martian mantle are inferred to be two to three times richer in $\mathrm{Cl}$ than corresponding terrestrial basalts and mantle (Dreibus \& Wänke, 1987; Filiberto \& Treiman, 2009; Taylor et al., 2010). This could, in theory, imply that chlorine rather than water is the main volatile in Martian basaltic magmas. However, the water content in the Martian mantle is still a matter of ongoing discussion (Grott et al., 2013; Gross et al., 2013). Volatile fugacity ratios in apatites from NWA 6234, an olivine-phyric shergottite (Filiberto et al., 2012) thought to represent a crystallised primitive melt (Musselwhite et al., 2006), suggest that the chlorine and water contents of the Martian mantle, parental to SNC meteorites, are higher than previously thought and similar to those of the mantle source of terrestrial mid-ocean ridge basalts (Gross et al., 2013).

Measurements from the Mars Odyssey gamma-ray spectrometer (GRS) revealed a global chlorine content of $0.49 \mathrm{wt} \%$ for the Mars surface (Keller et al., 2006), consistent with MER lander measurements of $\sim 0.3 \mathrm{wt} \%$ (Rao et al., 2002). Since these values are considerably higher than the chlorine abundance of the 


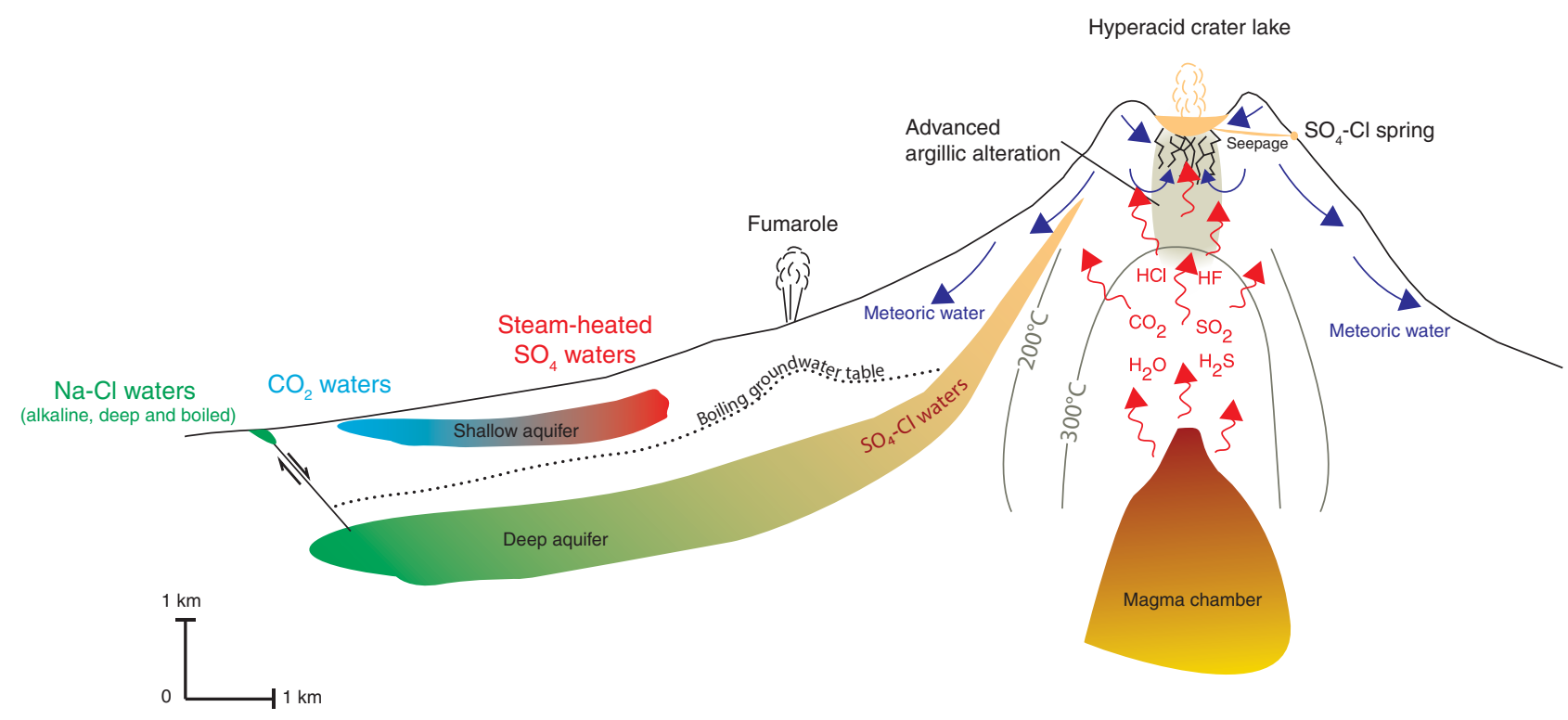

Fig. 1. Schematic profile depicting the distribution of fluid types and alteration zones in a crater lake hosting a stratovolcano setting. Modified from Henley \& Ellis (1983), Heald et al. (1987) and Arnórsson et al. (2007).

Martian mantle and crust (0.015-0.039 wt\%) (Lodders \& Fegley, 1997; Rao et al., 2002; Taylor et al., 2010) and SNC meteorites (0.0014-0.11 wt\%) (Dreibus \& Wänke, 1987; Banin et al., 1992), secondary processes are likely to be responsible for this enrichment (Keller et al., 2006). The NWA 6234 shergottite has a bulk $\mathrm{Cl}$ content of $59 \mathrm{ppm}$ and a $\mathrm{Br} / \mathrm{Cl}$ molar ratio of 0.0040 (Burguess et al., 2013), comparable to the molar $\mathrm{Br} / \mathrm{Cl}$ ratios of 0.0025 for Mars' bulk composition (Taylor et al., 2010). High contents of halogens (including $\mathrm{Cl}$ and $\mathrm{Br}$ ) and other elements with a strong affinity for aqueous solutions in rocks found at Barnhill (northwestern Home Plate, Gusev crater) point to interaction with briny fluids (Schmidt et al., 2008). The $\mathrm{Br} / \mathrm{Cl}$ molar ratios measured at Paso Robles (Gusev crater) by MER Spirit range from 0.0025 to 0.0399 (Yen et al., 2008). At Meridiani Planum, samples measured after the rock abrasion tool (RAT) exhibited $\mathrm{Br} / \mathrm{Cl}$ molar ratios of 0.025-0.00091 (Brückner et al., 2008). APXS analysis of sedimentary rocks at Yellowknife Bay (Gale crater) yielded $\mathrm{Br} / \mathrm{Cl}$ molar ratios between 0.097 and 0.016 (McLennan et al., 2014). Comparing all these $\mathrm{Br} / \mathrm{Cl}$ ratios to both NWA 6234 and Martian bulk values, it is likely that considerable elemental fractionation between these two halogens took place on the surface of Mars. APXS analyses on Martian rocks found on the surface show that bromine concentrations are low in basalt samples, but enriched in samples that have probably undergone weathering, evaporation and diagenesis (Rieder et al., 2004; Clark et al., 2005). Zhao et al. (2014) concluded that the observed variability in $\mathrm{Br} / \mathrm{Cl}$ ratios is largely controlled by $\mathrm{Br}$ abundances.

From the negative correlation between the $\mathrm{Cl}$ content of surface materials, thermal inertia and rock abundance, and the positive correlation with albedo, Keller et al. (2006) hypothesised that fine, mobile aeolian materials are enriched in $\mathrm{Cl}$. Nevertheless, the uneven distribution of $\mathrm{Cl}$ contents, with en- richments in the equatorial regions close to Tharsis Montes, suggests that additional processes must have played a role in concentrating chlorine on Mars' surface, such as evaporite deposition (Clark et al., 2005; McLennan et al., 2005), chemical alteration through hydrothermal activity (Schmidt et al., 2008; Yen et al., 2008), acid-fog reactions associated with volcanic exhalations (Arvidson et al., 2004; Tosca el al., 2004) and photochemical oxidation (Marion et al., 2010; Hanley et al., 2012; Kounaves et al., 2014).

\section{Earth observations}

\section{Volcanic hydrothermal systems}

Hydrothermal systems consist of a body of hot rock whose permeability is enough for a fluid to circulate and obtain heat from the rock under certain temperature and pressure conditions. This scenario can occur in various geological settings. Volcanic hydrothermal systems are found in areas with active volcanism where the geothermal gradient and rock permeability are usually high. The heat source may be a major magma intrusion or a complex of dykes or minor intrusions. When a magma body rises towards the surface, diminishing lithostatic pressures decrease the solubility of volatiles present in the melt. Also, crystallisation of a cooling magma reservoir after its emplacement will promote volatile saturation in the residual melt. In both cases, volatiles can ultimately exsolve, causing degassing. The volatiles mainly consist of $\mathrm{H}_{2} \mathrm{O}, \mathrm{CO}_{2}, \mathrm{SO}_{2}$, $\mathrm{H}_{2} \mathrm{~S}, \mathrm{HCl}, \mathrm{HF}$ and $\mathrm{HBr}$ (Symonds \& Reed, 1993). These magmatic components can react with host rocks, escape to the surface or condense in cold groundwater, creating extremely acid fluids ( $\mathrm{SO}_{4}$-Cl-type waters) (Fig. 1). The acidity comes primarily 
from the bisulphate ion $\left(\mathrm{HSO}_{4}^{-}\right)$, produced by the aqueous dissolution of $\mathrm{SO}_{2(g)}$ and its disproportionation (Kusakabe et al. 2000; Symonds et al., 2001). In addition, $\mathrm{HCl}_{(\mathrm{g})}$ significantly contributes to acidity because of its high aqueous solubility. If local boiling of deep fluids produces vapour that enters shallow aquifers, $\mathrm{SO}_{4}$-type waters are produced. Since the $\mathrm{pH}$ of both $\mathrm{SO}_{4}$-Cl- and $\mathrm{SO}_{4}$-type waters is low $(<3)$, their interaction with rocks promotes uptake of cations by the solution and hydrothermal alteration, which is commonly recorded by mineralogical, textural and chemical changes in the original rock. Which secondary mineral assemblages are formed is a function of many parameters such as temperature, pressure, type of primary fluids involved (e.g. meteoric, seawater), acid supply, rock composition and the water-rock ratio (which is related to permeability).

Advanced argillic alteration in internal zones of volcanoes (Fig. 1) is caused by rock leaching with acid waters that contain residual magmatic volatiles. A porphyritic rock can become completely silicified, with silica replacing the groundmass as well as phenocrysts. The silicification is surrounded by alunite-rich alteration and subsequently by kaolinite (Steiner, 1977; Heald et al., 1987). Deeper levels may contain phyrophyllite, diaspore and dickite, and regionally chlorite, albite, calcite and pyrite alteration (Einaudi et al., 2003). The cation-rich acidic brine that leaves a silica-rich residue is capable of forming $\mathrm{Mg}, \mathrm{Fe}, \mathrm{Ca}$ and eventually $\mathrm{Al}$ sulphates, depending on water/rock ratios and temperatures (Tosca et al., 2004; 2005; Tosca \& McLennan, 2006). Examples of this alteration style can be observed around fumaroles and in crater settings with a hyperacid volcanic lake. At greater distances from the heat source (magma body), an adularia-sericite-type deposit can form where superficial waters mix with deeper, heated saline waters in a lateral flow system. In this case neutral to weakly acidic, alkali chloride silica-saturated waters are dominant (Heald et al., 1987).

\section{Acid crater lakes}

Hyperacid volcanic lakes are surface expressions of volcanichydrothermal systems and are the result of the interaction of a rising magmatic gas/fluid of deep origin and a body of meteoric water derived from rain and/or snow melt. The temperatures of the $\mathrm{SO}_{4}$-Cl-type waters of these lakes range from ca. 45 to $60^{\circ} \mathrm{C}$, and $\mathrm{pH}$ values are commonly below 2 (Pasternack \& Varekamp, 1997; Varekamp et al., 2000). The acid volcanic lakes and their associated alteration zones in host craters usually cover areas ranging from a few to tens of $\mathrm{km}^{2}$ (Rowe et al., 1992; Africano \& Bernard, 2000; Delmelle et al., 2000; Kempter $\&$ Rowe, 2000). In many cases, active fumaroles are also present (Fig. 2).

The most active lakes $(\mathrm{pH}=1)$ are hyperacid brines, with $\mathrm{SO}_{4}$ and $\mathrm{Cl}$ contents between 1000 and 100,000 ppm, together with major cations ( $\mathrm{Al}, \mathrm{Fe}$ and $\mathrm{Ca}$ ) often into the thousands of ppm (e.g. Delmelle et al., 2000; Kempter \& Rowe, 2000;
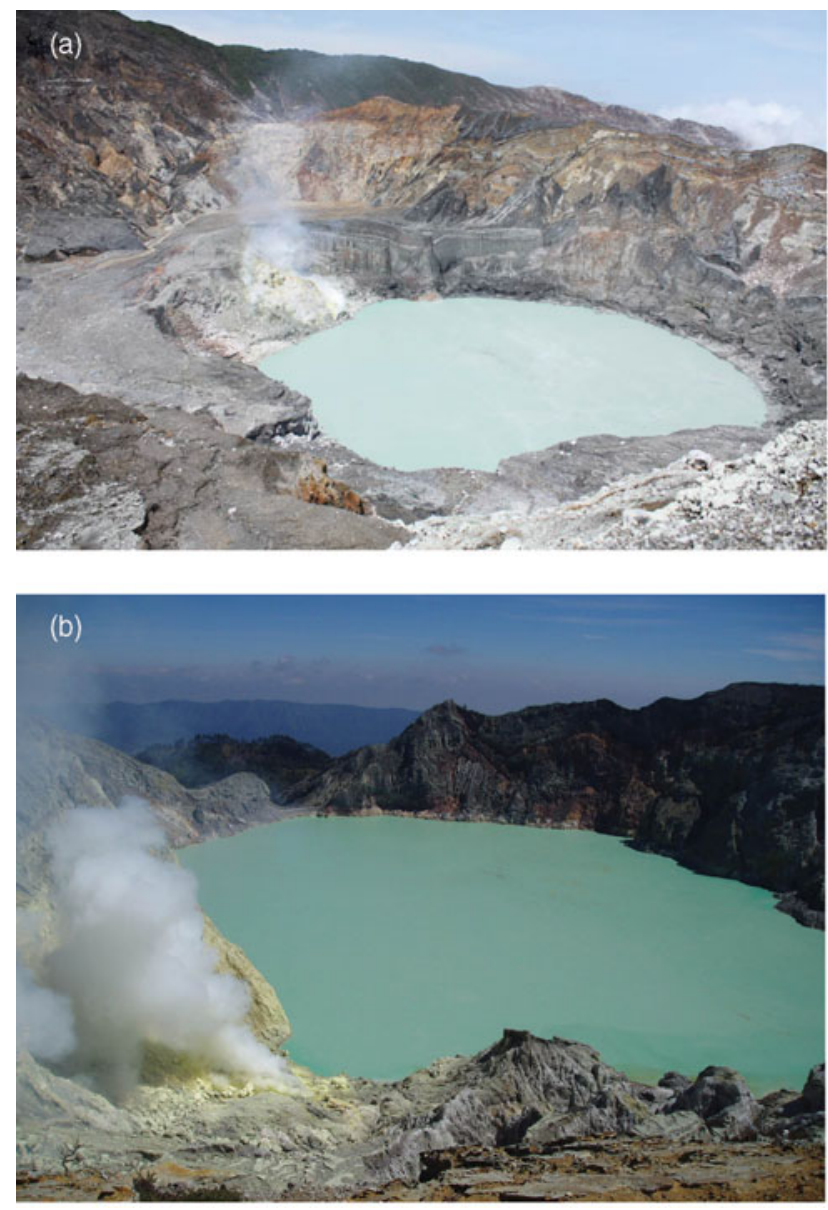

Fig. 2. Hyperacid lakes of (a) Poás volcano (Costa Rica) and (b) Kawah Ijen (east Java, Indonesia).

Varekamp et al., 2000, 2009; Gammons et al., 2005; Martínez, 2008). Volcanoes with well-known examples of such lakes are: Poás (Costa Rica, Fig. 2a), Kawah Ijen (Indonesia, Fig. 2b), Ruapehu (New Zealand), Kusatsu-Shirane (Japan), Rincón de La Vieja (Costa Rica) and Copahue (Argentina). The $\mathrm{SO}_{4}$-Cl-type surface waters in stratovolcanoes are not always confined to crater lakes but can also be issued from springs on the flank close to the active crater, either as seepage water from the lake or as an independent outlet of the subsurface hydrothermal system.

\section{Sulphates and silica-rich deposits}

Amorphous silica, gypsum $\left(\mathrm{CaSO}_{4} \cdot 2 \mathrm{H}_{2} \mathrm{O}\right)$, elemental sulphur $(\mathrm{S})$, barite $\left(\mathrm{BaSO}_{4}\right)$ and anatase $\left(\mathrm{TiO}_{2}\right)$ are saturated in many of these waters, and are commonly present as chemical precipitates in the water column and in lake-bottom sediments (e.g. Delmelle \& Bernard, 1994; Varekamp et al., 2000; Martínez, 2008). In the bottom sediments of Poás, Kawah Ijen and Copahue hyperacid lakes, where rather reducing conditions tend to prevail, pyrite $\left(\mathrm{FeS}_{2}\right)$ and other sulphides are also found. Although aggressive leaching usually leaves a bleached, silica-rich residue of 
volcanics in lake-hosting crater areas, silica is supplied by input of hot fluids. Cooling leads to continuous chemical sedimentation of amorphous silica, with gypsum as the most abundant associated sulphate (Fig. 4c).

Furthermore, if we calculate saturation indices for hyperacid waters of Poás and Copahue, it appears that in deeper parts of these volcanic systems, where temperatures are considerably higher, minerals such as hematite $\left(\mathrm{Fe}_{2} \mathrm{O}_{3}\right)$, diaspore $[\alpha$ $\mathrm{AlO}(\mathrm{OH})]$ and alunite $\left[\left(\mathrm{K}, \mathrm{Na}, \mathrm{H}_{3} \mathrm{O}\right) \mathrm{Al}_{3}\left(\mathrm{SO}_{4}\right)_{2}(\mathrm{OH})_{6}\right]$ become oversaturated and thus prone to precipitation. We could confirm the presence of alunite, in combination with quartz and elemental sulphur, in ancient fumarole fields at Poás and in clasts ejected during the December 2012 eruption of Copahue. Jarosite $\left[\left(\mathrm{K}, \mathrm{Na}, \mathrm{H}_{3} \mathrm{O}\right) \mathrm{Fe}_{3}\left(\mathrm{SO}_{4}\right)_{2}(\mathrm{OH})_{6}\right]$, in association with amorphous silica and iron oxides has been found at Poás as an alteration product between lavas and acid rain. A closer examination of the alteration products revealed that amorphous silica is present in the outer parts of the rocks as a patina, and that the alteration proceeded to form jarosite and eventually iron oxides (Fig. 3). Jarosite is also abundant around the Río Agrio spring $\left(T=52^{\circ} \mathrm{C}\right.$, $\mathrm{pH}=0.49$ ) at the Copahue volcano (Fig. 4). Its water has been saturated with jarosite and alunite since 2000 (Varekamp et al., 2009).

We found a wide range of other hydrous sulphates in the environments with hyperacid lakes, springs and streams that apparently formed as efflorescence products. Efflorescence of gypsum $\left(\mathrm{CaSO}_{4} \cdot 2 \mathrm{H}_{2} \mathrm{O}\right)$, natrojarosite $\left(\mathrm{NaFe}_{3}\left(\mathrm{SO}_{4}\right)_{2}(\mathrm{OH})_{6}\right)$, khademite $\left(\mathrm{Al}\left(\mathrm{SO}_{4}\right) \mathrm{F} \cdot 5 \mathrm{H}_{2} \mathrm{O}\right)$, ferricopiapite $\quad\left(\mathrm{Fe}_{0.67}{ }^{3+} \mathrm{Fe}_{4}{ }^{3+}\left(\mathrm{SO}_{4}\right)_{6}(\mathrm{OH})_{2} \cdot 20 \mathrm{H}_{2} \mathrm{O}\right)$, magnesiocopiapite $\left(\mathrm{MgFe}_{4}{ }^{3+}\left(\mathrm{SO}_{4}\right)_{6}(\mathrm{OH})_{2} \cdot 2 \mathrm{H}_{2} \mathrm{O}\right)$ and voltaite $\left(\mathrm{K}_{2} \mathrm{Fe}_{5}{ }^{2+} \mathrm{Fe}_{3}{ }^{3+} \mathrm{Al}\left(\mathrm{SO}_{4}\right)_{12} \cdot 18 \mathrm{H}_{2} \mathrm{O}\right)$, as well as epsomite $\left(\mathrm{MgSO}_{4} \cdot 7 \mathrm{H}_{2} \mathrm{O}\right)$, hexahydrite $\left(\mathrm{MgSO}_{4} \cdot 6 \mathrm{H}_{2} \mathrm{O}\right)$, pentahydrite $\left(\mathrm{MgSO}_{4} \cdot 5 \mathrm{H}_{2} \mathrm{O}\right)$ and kieserite $\left(\mathrm{MgSO}_{4} \cdot \mathrm{H}_{2} \mathrm{O}\right)$ are present in the Copahue area, and epsomite at Poás. Field observations indicate that their occurrence is related to fumaroles and to rock crusts where probably limited water-rock interaction, in combination with evaporation, has taken place. Efflorescence products on the borders of a hyperacid seepage stream derived from Kawah Ijen lake include potassium alum $\left(\mathrm{KAl}\left(\mathrm{SO}_{4}\right)_{2} \cdot 2 \mathrm{H}_{2} \mathrm{O}\right)$, gypsum, alunogen $\left(\mathrm{Al}_{2}\left(\mathrm{SO}_{4}\right)_{3} \cdot 2 \mathrm{H}_{2} \mathrm{O}\right)$, voltaite and melanterite $\left(\mathrm{FeSO}_{4} \cdot 7 \mathrm{H}_{2} \mathrm{O}\right)$.

\section{Chlorine and bromine abundances}

Halogens $\left(\mathrm{Cl}, \mathrm{F}\right.$ and $\mathrm{Br}$ ) are, after $\mathrm{H}_{2} \mathrm{O}, \mathrm{SO}_{2}$ and $\mathrm{CO}_{2}$, the most abundant volatiles in volcanic systems on Earth (Aiuppa et al., 2009). In subareal fumarolic emissions they are commonly present as their correspondent hydrogen compounds: $\mathrm{HCl}_{(\mathrm{g})}$, $\mathrm{HF}_{(\mathrm{g})}$ and $\mathrm{HBr}_{(\mathrm{g})}$. These gases dissociate quite easily in water and are therefore key contributors to the aqueous budgets of $\mathrm{H}^{+}, \mathrm{Cl}^{-}, \mathrm{F}^{-}$and $\mathrm{Br}^{-}$. In $\mathrm{SO}_{4}-\mathrm{Cl}$-type waters, chlorine is the most abundant halogen, followed by fluorine and bromine. The differences in abundances between the halogens are signifi-
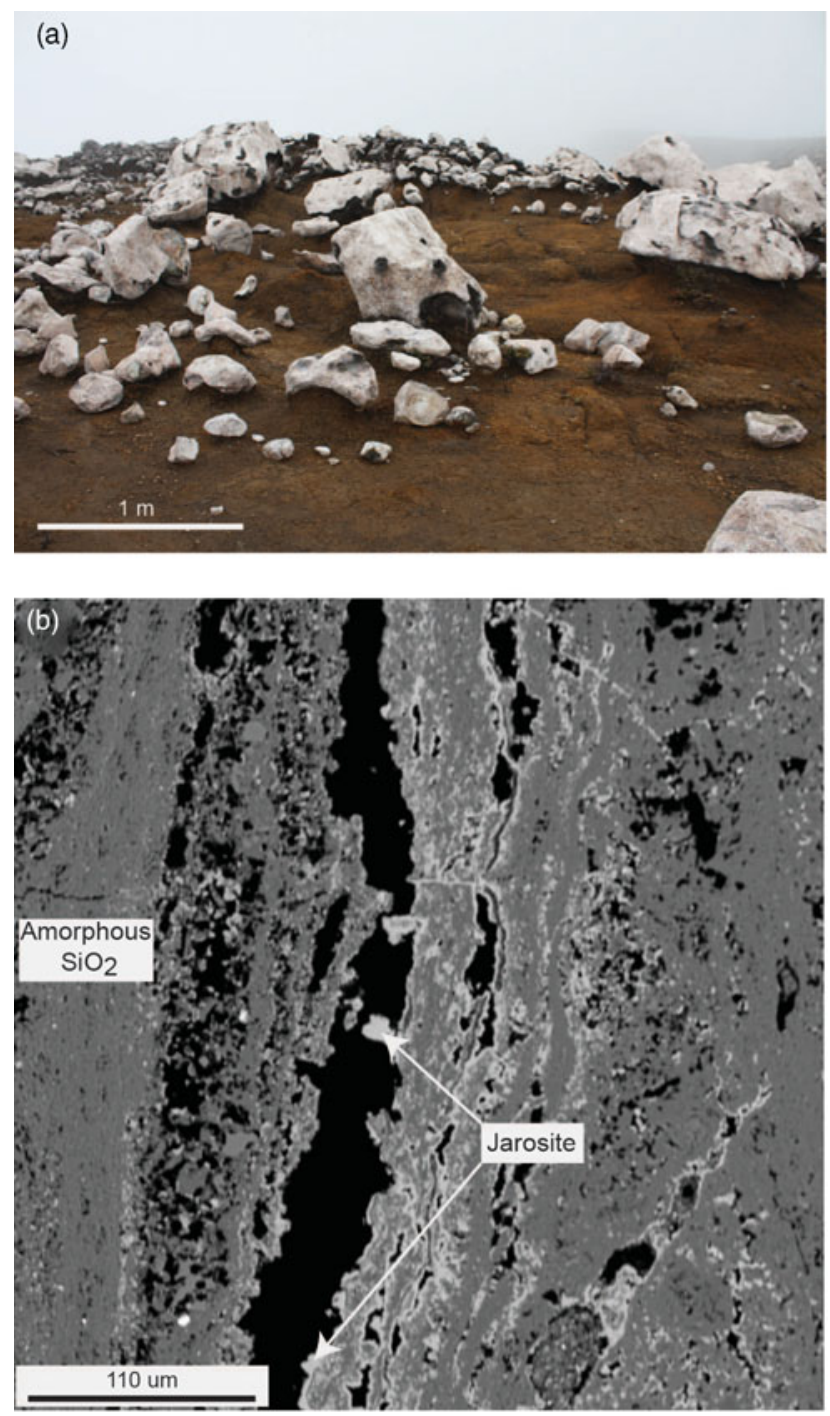

Fig. 3. (a) Leached lava blocks at Cerro Pelón (Poás volcano, Costa Rica) showing white crusts of amorphous silica. Iron oxides are abundant in soils. (b) Electron back-scatter image of one of the blocks. Amorphous silica precipitation is probably followed by jarosite formation.

cant. In volcanic systems like Poás, Rincón de La Vieja, Copahue and Kawah Ijen (Martínez, 2008; Kempter \& Rowe, 2000; Varekamp et al., 2009; Delmelle \& Bernard, 1994), where $\mathrm{Cl}^{-}$is normally present in concentrations of tens of thousands of $\mathrm{ppm}$, $\mathrm{F}^{-}$abundances are in the order of thousands of $\mathrm{ppm}$ and $\mathrm{Br}^{-}$ in concentrations of tens of ppm. Both chlorine and bromine are hydrophile elements and behave as conservative elements in most natural systems, meaning that their abundances are only dependent on dilution and concentration processes. During a very intense period of volcanic activity at Poás at the end of the 1980s, samples from the hyperacid lake revealed $\mathrm{Br} / \mathrm{Cl}$ ratios up to 0.0092 (Martínez, 2008), within the values for Paso Robles soils (Gusev crater) reported by Yen et al. (2008). 

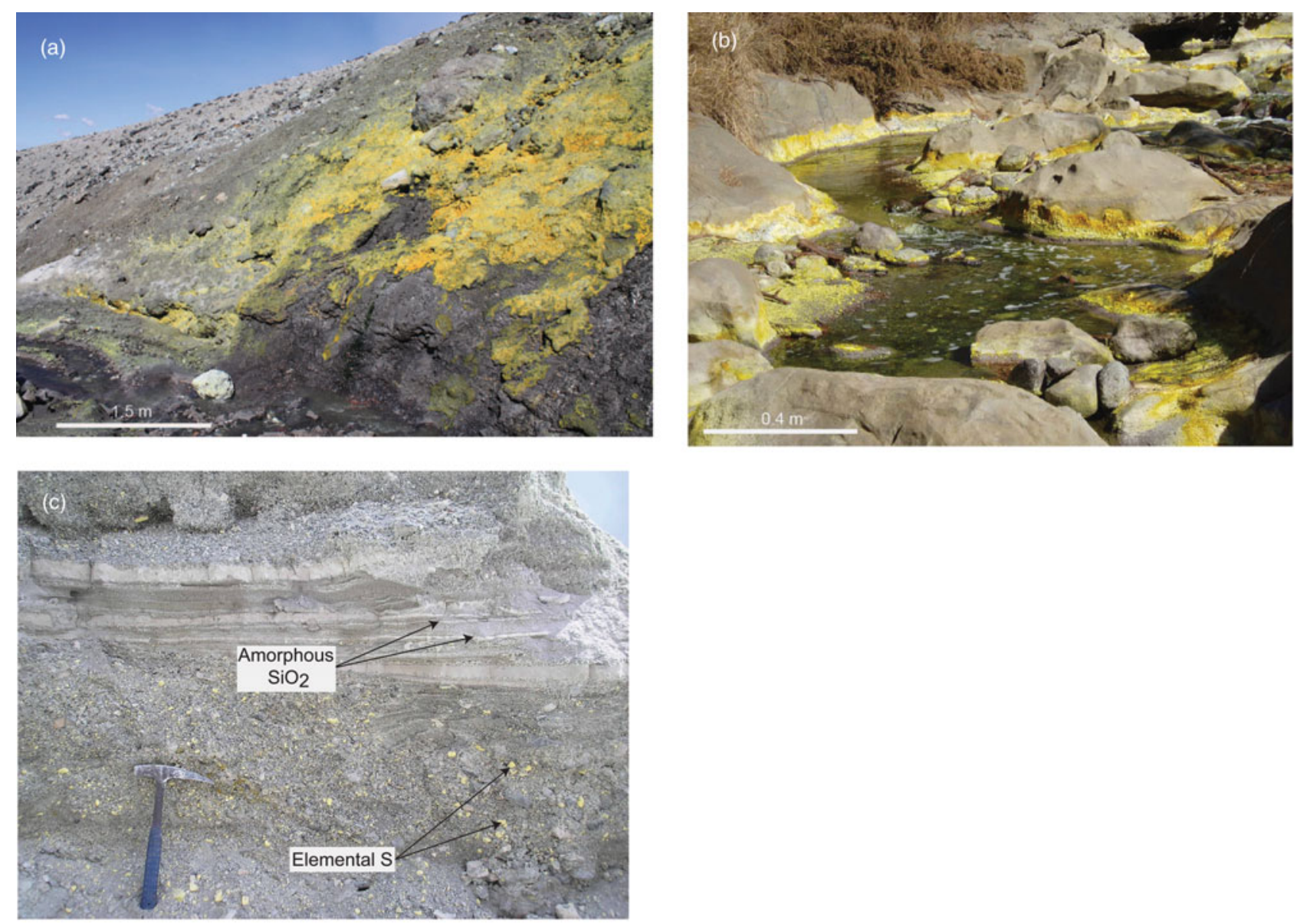

Fig. 4. (a) Efflorescence of gypsum $\left(\mathrm{CaSO}_{4} \cdot 2 \mathrm{H}_{2} \mathrm{O}\right)$, natrojarosite $\left[\mathrm{NaFe}_{3}\left(\mathrm{SO}_{4}\right)_{2}(\mathrm{OH})_{6}\right]$, khademite $\left[\mathrm{Al}\left(\mathrm{SO}_{4}\right) \mathrm{F} \cdot 5 \mathrm{H}_{2} \mathrm{O}\right]$, ferricopiapite $\left[\mathrm{Fe}_{0.67}{ }^{3+} \mathrm{Fe}_{4}{ }^{3+}\left(\mathrm{SO}_{4}\right)_{6}(\mathrm{OH})_{2} \cdot 2 \mathrm{H}_{2} \mathrm{O}\right]$, magnesiocopiapite $\left[\mathrm{MgFe}_{4}{ }^{3+}\left(\mathrm{SO}_{4}\right)_{6}(\mathrm{OH})_{2} \cdot 2 \mathrm{OH}_{2} \mathrm{O}\right]$, epsomite $\left(\mathrm{MgSO}_{4} \cdot 7 \mathrm{H}_{2} \mathrm{O}\right)$ and voltaite $\left[\mathrm{K}_{2} \mathrm{Fe}_{5}{ }^{2+} \mathrm{Fe}_{3}{ }^{3+} \mathrm{Al}\left(\mathrm{SO}_{4}\right)_{12} \cdot 18 \mathrm{H}_{2} \mathrm{O}\right]$ close to Río Agrio hot spring, Copahue (Argentina). (b) Efflorescence of potassium alum [KAl( $\left.\left.\mathrm{SO}_{4}\right)_{2} \cdot 2 \mathrm{H}_{2} \mathrm{O}\right]$, gypsum, alunogen $\left[\mathrm{Al}_{2}\left(\mathrm{SO}_{4}\right)_{3} \cdot 2 \mathrm{H}_{2} \mathrm{O}\right]$, voltaite and melanterite $\left(\mathrm{FeSO}_{4} \cdot 7 \mathrm{H}_{2} \mathrm{O}\right)$ at the Banyupahit stream, which is fed by seepage water of the hyper acid Kawah Ijen lake (east Java, Indonesia). (c) Amorphous silica layers and elemental sulphur chunks within exposed lake deposits of Kawah Ijen.

\section{Discussion}

The vast literature on surface mineralogy of Mars, summarised above, lends support to the hypothesis that volcanic interaction with subsurface hydrologic reservoirs below and on the surface has played an important role in creating secondary mineral assemblages in Martian geological history. Importantly, the presence of sulphate-rich deposits, silica and iron oxides together with enrichments in the halogens $\mathrm{Cl}$ and $\mathrm{Br}$ suggests that the fluids involved were probably highly acidic and rich in elements like $\mathrm{Fe}, \mathrm{Al}, \mathrm{Ca}, \mathrm{Si}, \mathrm{S}, \mathrm{Cl}$ and $\mathrm{Br}$. These fluids are probably similar to $\mathrm{SO}_{4}$-Cl- and $\mathrm{SO}_{4}$-type waters in volcanic hydrothermal systems on Earth, which therefore provide opportunities to study the formation of Mars-type mineralogies in situ.

We have highlighted the relevance of volcanic settings with hyperacid lakes and associated acid springs, streams and fumarolic exhalations, in view of the range of secondary mineral associations that volcanic hydrothermal systems produce. Although documented examples are mostly from settings in the subduction zone, different from the Martian context where plate tectonics probably do not operate and volcanism may have been associated with mantle plumes (Grott et al., 2013), fluidrock interaction processes on Earth can probably explain many of the sulphate-bearing mineral associations found on Mars.

\section{Mineral assemblages}

The acidity of $\mathrm{SO}_{4}$-Cl-type waters in volcanic hydrothermal systems makes them highly reactive and capable of leaching cations from the phenocrysts and groundmass of surrounding volcanic rocks, so that often only a residue of amorphous silica or kaolinite $\left[\mathrm{Al}_{2} \mathrm{Si}_{2} \mathrm{O}_{5}(\mathrm{OH})_{4}\right]$ is left. From these enriched waters, $\mathrm{Ca}-, \mathrm{Al}-, \mathrm{Fe}-$ and $\mathrm{Mg}$-sulphates can form as product of subsequent water-rock interaction and/or evaporation. These associations are not very different from evaporite mineralogies on Mars, which seem to be dominated by $\mathrm{Mg}$, Fe and Ca sulphates and silica phases, probably due the basaltic compositions of the crust, prevailing acidic regimes and relatively low water/rock 
ratios (Tosca et al., 2004; Tosca \& McLennan, 2006). In contrast, seawater evaporites on Earth are typically dominated by halite, calcite, anhydrite and various $\mathrm{K}$ and $\mathrm{Na}$-chlorides and sulphates (Braitsch, 1971).

Siliceous deposits on Earth are mostly formed as a residue of acid rock leaching in volcanic terrains (advanced argillic alteration) or as precipitates from hot near-neutral to alkaline aqueous solutions saturated with amorphous silica in the distal parts of volcanic hydrothermal systems or from acid volcanic lakes receiving an input of hot solutions. Siliceous sinters are excellent indicators of the presence of hydrothermal reservoirs with temperatures $>175^{\circ} \mathrm{C}$ (Fournier \& Rowe, 1966). On Mars, there is evidence for silica formation both as a product of acid leaching and as precipitate from acid and alkaline hot fluids (Miliken et al., 2008; Mustard et al., 2008; Ruff et al., 2011).

As recently documented for gas-dominated settings at active volcanoes in Nicaragua (Hynek et al., 2013; Marcucci et al., 2013), environmental parameters such as temperature, $\mathrm{pH}$, rock and fluid composition, and fluid-rock ratio will exert strong controls on the nature and extent of the alteration mineralogy. Local variability in secondary mineral assemblages is further promoted by steep gradients in temperature, $\mathrm{pH}$ and oxidation state.

\section{Chlorine and bromine fractionation}

Hydrobromic acid $\left(\mathrm{HBr}_{(\mathrm{ac})}\right)$ is a stronger acid than hydrochloric acid $\left(\mathrm{HCl}_{(\mathrm{ac})}\right)$, so the former tends to dissociate less in aqueous solutions than the latter. Evaporation is therefore expected to fractionate $\mathrm{Cl}$ and $\mathrm{Br}$ in a solution. For example, when the acidy of a crater lake increases in response to increased input of volatiles and heat, $\mathrm{HCl}_{(\mathrm{g})}$ could be expelled with the vapour phase to a greater extent than $\mathrm{HBr}_{(\mathrm{g})}$, increasing the $\mathrm{Br} / \mathrm{Cl}$ ratio of the water. The association of $\mathrm{Br}$ and $\mathrm{Cl}$ with $\mathrm{S}$, together with textural evidence for a volcaniclastic origin of deposits in Gusev crater (Squyres et al., 2007; Yen et al., 2008) suggest that acid fluids from a volcanic system could have had a major role in the formation of soils in this area. At Meridiani Planum, variable chloride and bromide concentrations have been attributed to low water availability (Clark et al., 2005) as this would imply that bromides (the most soluble salts) could have migrated further than chlorides. Alternative $\mathrm{Br}-\mathrm{Cl}$ fractionation mechanisms involving acid solutions in an active volcanic setting should also be taken into account. In contrast, the secondary mineralogy at Gale Crater indicates that the fluids involved in the water-rock interaction were probably neutral (McLennan et al., 2014).

\section{Geochemical modelling}

To illustrate a formation sequence of secondary minerals as a product of the reaction between $\mathrm{SO}_{4}$-Cl-type waters and surrounding igneous rocks, we modelled a reaction path with
PHREEQC (Parkhust \& Appelo, 1999), in which a basalticandesite from the last eruption of the Copahue volcano (22 December 2012) was reacted with water from the Río Agrio acid hot spring (sample collected on 19 March 2013) at $25^{\circ} \mathrm{C}$. This hot spring $\left(T=52^{\circ} \mathrm{C}, \mathrm{pH}=0.49\right)$ is close to the active crater of Copahue and most likely represents the fluids circulating within this volcanic hydrothermal system (Varekamp et al., 2009). This reaction path model is essentially a titration model in which small amounts of rock are progressively added to a fixed mass of water. The reaction progress is a parameter employed here to describe how evolved a system is in terms of moles of rock that have reacted with the amount of water. The modelling results strongly depend on the phases (secondary minerals) that are allowed to precipitate or that are supressed. Choices were made based on a survey of the secondary mineralogy in the field.

The sequence of minerals that are stabilised as function of the water/rock ratio or reaction progress is shown in Fig. 5. At lower reaction progress values $(<0.01$ mole rock $/ \mathrm{kg}$ water) the mineral association consists of amorphous silica and anatase. Gypsum appears at intermediate reaction progress values (0.01-0.1 mole rock $/ \mathrm{kg}$ water). Finally, at higher reaction progress values ( $>0.1$ mole rock/ $\mathrm{kg}$ water) jarosite $\left[\mathrm{KFe}_{3}\left(\mathrm{SO}_{4}\right)_{2}(\mathrm{OH})_{6}\right]$, jurbanite $\left[\mathrm{Al}(\mathrm{OH}) \mathrm{SO}_{4} \cdot 5 \mathrm{H}_{2} \mathrm{O}\right]$, hematite $\left(\mathrm{Fe}_{2} \mathrm{O}_{3}\right)$, alunite $\left[\mathrm{KAl}_{3}\left(\mathrm{SO}_{4}\right)_{2}(\mathrm{OH})_{6}\right]$, kaolinite $\left[\mathrm{Al}_{2} \mathrm{Si}_{2} \mathrm{O}_{5}(\mathrm{OH})_{4}\right]$ and eventually smectites $(\mathrm{Mg}$ and $\mathrm{K}$ montmorillonites) are formed. In general, the initial alteration stages are dominated by sulphates (low reacted system) and the later ones by smectites (high reacted system). The mineral assemblage at low to intermediate reaction progress is in good agreement with field observation at the Río Agrio spring surroundings. To evaluate the temperature effect in the overall water-rock interaction, reaction path models were also carried out at 50,75 and $100^{\circ} \mathrm{C}$ (not shown). The results indicate that jarosite does not form above $50^{\circ} \mathrm{C}$ and hematite takes over as the main Fe-bearing phase. In addition, Na-alunite $\left[\mathrm{NaAl}_{3}\left(\mathrm{SO}_{4}\right)_{2}(\mathrm{OH})_{6}\right]$ together with alunite form at lower reaction progress values and phillipsite (zeolite) appears at $75^{\circ} \mathrm{C}$.

Experiments and models simulating alteration of basaltic rocks with sulphuric acid solutions have shown similar alteration trends for iron and calcium sulphates, and have supported the hypothesis that Martian sulphate terrains are the product of a limited water-rock interaction under extremely acid environments (Tosca et al., 2004; Golden et al., 2005; Tosca \& McLennan, 2006; King et al., 2011; Hausrath et al., 2013; McCollom et al., 2013; Marcucci et al., 2013). Our model shows overall similarities with experimental results on basaltic material at lower reaction progress values but differs with respect to the appearance of aluminium sulphates (alunites and jurbanite). Alunite group minerals were also found to be stable in thermochemical models of interaction between fumarole condensate and dacite rock (Africano \& Bernard, 2000) and are probably quite common among the secondary sulphates in the summit regions of active andesitic volcanoes where magmatic 


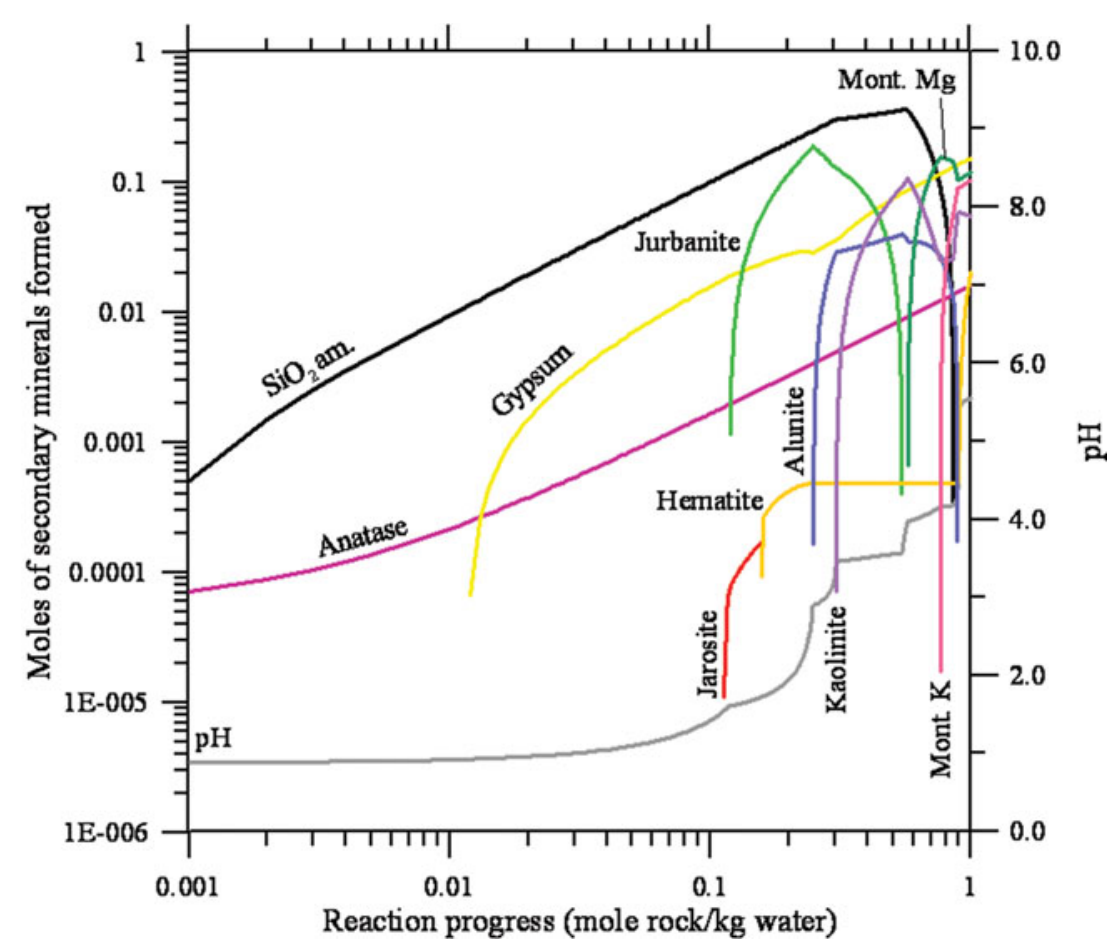

Fig. 5. Titration model in which $1 \mathrm{~mol}(110 \mathrm{~g})$ of andesite rock from the Copahue eruption of 22 December 2012 (Camfield, 2013; pers. com.) was reacted with $1 \mathrm{~kg}$ of water from Río Agrio spring collected on 19 March 2013. fluids escape (Zimbelman et al., 2005; Scher et al., 2013). The low abundance of aluminium sulphates on Mars has been taken as an indication for limited water-rock interaction (Tosca \& McLennan, 2006).

\section{Alternative formation mechanisms for sulphate-rich assemblages}

Acid mine drainage (AMD) has also been proposed as a terrestrial analogue setting for Martian sulphate-rich terrains. Río Tinto, in Spain, is probably one of the most studied examples (FernándezRemolar et al., 2005, 2011; Fernández-Remolar \& Knoll, 2008). In AMD environments, acid fluids commonly originate by means of pyrite oxidation. Since pyrite is a common secondary mineral in volcanic hydrothermal systems where reducing conditions prevail, its oxidation clearly has the potential to generate acid conditions similar to AMD systems. The source of the sulphur that lead to the formation of the massive sulphate deposits within Valles Marineris has been related to the presence of crustal sulphide deposits (i.e. pyrite) (Burns \& Fisher, 1993; Chevrier et al., 2004, 2006). While metal sulphide deposits have not been directly detected on the surface of Mars, their presence has been hinted at for a long time (Clark et al., 1982; Burns \& Fisher, 1990, 1993; Baker et al., 1991; Chevrier et al., 2006).

Permian acid-saline lake deposits in Kansas (USA), and their modern counterparts in southwestern Australia, show many analogies to the Martian Burns Formation in terms of mineralogy and sedimentary structures (Benison \& Goldstein, 2001; Benison, 2006; Benison et al., 2007; Baldridge et al., 2009; Story et al., 2010). The waters of these lakes are very shallow, inducing significant seasonal fluctuations in evaporation rates, which provide a mechanism to separate the most soluble salts (Mg-sulphates and $\mathrm{Mg}$ bromide) from less soluble compounds in residual brines. There are important compositional differences with acid volcanic hydrothermal systems. While the Australian lakes typically exhibit a $\mathrm{Na}-\mathrm{Mg}-\mathrm{Cl}-\mathrm{SO}_{4}$ composition with variable but locally large amounts of $\mathrm{Ca}, \mathrm{K}, \mathrm{Al}, \mathrm{Fe}, \mathrm{Si}$ and $\mathrm{Br}$ (Benison \& Bowen, 2006), the volcanic brines have an Al-Fe-Ca-SO ${ }_{4}-\mathrm{Cl}$ composition and have a higher potential of forming $\mathrm{Al}$ and $\mathrm{Fe}$ sulphates. In contrast, $\mathrm{Mg}$-sulphates could be more common in the Australian brines.

The extension and scale of mineral alteration and precipitation of secondary minerals from hot fluids associated with a magmatic body are not necessarily the same for Mars and Earth systems. The lower surface gravity on Mars (about 38\% that of the Earth) results in a smaller lithostatic pressure gradient, implying differences in buoyancy-driven processes such as the ascent of magma diapirs (Grott et al., 2013). Since the density contrasts between magmas and host rock are considered to be similar on both planets, magma bodies should rise more slowly on Mars and, in order to reach crustal levels before cooling and solidification, they should be larger than on Earth (Wilson \& Head, 1994). Moreover, as Wilson and Head (1994) predicted, the minimum water content of Martian magmas needed to generate an explosive eruption is $0.0014 \mathrm{wt} \%$, two orders of magnitude lower than the amount in their terrestrial counterparts $(0.24 \mathrm{wt} \%)$. Finally, because of the thinner Martian atmosphere, particles from an explosive eruption would have travelled over greater distances on Mars than on Earth, so that geomorphological features associated to explosive 
volcanism might differ between the two planets (Broz \& Hauber, 2012, 2013). From these considerations it is conceivable that volcanic hydrothermal processes and products of acid systems have occurred at larger scales on Mars.

\section{Concluding remarks}

Surface expressions of volcanic hydrothermal systems on Earth share many similarities with Mars' sulphate-rich terrains in terms of alteration mineralogy and element distributions. Because volcanism has been an important process in Mars' geological history, it is likely to have produced a similar range of aggressive fluids that can be observed in the surface environment of active terrestrial volcanoes where the effects of interaction with rocks and mobilisation elements are directly observable. Hence, examining secondary mineral assemblages, styles of alteration, mechanisms of fluid-solid interactions and distributions of mobile components in volcanic settings will shed light on processes that could have occurred on Mars, and will help establish for which of the many Martian sulphate-bearing sites volcanic hydrothermal systems make good analogues.

\section{Acknowledgements}

Funding for this work was provided by the Netherlands 0rganization for Scientific Research, project ALW-G0-PL/10-03. We thank Jessica Flahaut and an anonymous referee for their careful reviews and valuable comments, which improved this manuscript considerably.

\section{References}

Abramov, O. \& Kring, D.A., 2005. Impact-induced hydrothermal activity on early Mars. Journal of Geophysical Research 110: E12S09. doi: 10.1029/2005JE002453.

Africano, F. \& Bernard, A., 2000. Acid alteration of the fumarolic environment of Usu volcano, Hokkaido, Japan. Journal of Volcanology and Geothermal Research 97: 475-495.

Aiuppa, A., Baker, D.R. \& Webster, J.D., 2009. Halogens in volcanic systems. Chemical Geology 263: 1-18.

Arnórsson, S., Stefánsson, A. \& Bjarnason, J.0̈., 2007. Fluid-fluid interactions in geothermal systems. In: Liebscher, A. \& Heinrich, C. (eds): Reviews in Mineralogy and Geochemistry, volume 65. The Mineralogical Society of America (Virginia): 259-312.

Arvidson, R.E., Anderson, R.C., Bartlett, P., Bell, J.F., Christensen, P.R., Chu, P., Davis, K., Ehlmann, B.L., Golombek, M.P., Gorevan, S., Guinness, E.A., Haldemann, A.F.C., Herkenhoff, K.E., Landis, G., Li, R., Lindemann, R., Ming, D.W., Myrick, T., Parker, T., Richter, L., Seelos, F.P., Soderblom, L.A., Squyres, S.W., Sullivan, R.J. \& Wilson, J., 2004. Localization and physical property experiments conducted by opportunity at Meridiani Planum. Science 306: 1730-1733.
Baird, A., Toulmin, P., Clark, B., Rose, H., Keil, K., Christian, R. \& Gooding, J., 1976. Mineralogic and petrologic implications of Viking geochemical results from Mars. Science 194: 1288-1293.

Baker, V., Strom, R., Gulick, V., Kargel, J., Komatsu, G. \& Kale, V., 1991. Ancient oceans, ice sheets and the hydrological cycle on Mars. Nature 352: 589-594.

Baldridge, A.M., Hook, S.J., Crowley, J.K., Marion, G.M., Kargel, J.S., Michalski, J.L., Thomson, B.J., de Souza Filho, C.R., Bridges, N.T. \& Brown, A.J., 2009. Contemporaneous deposition of phyllosilicates and sulfates: Using Australian acidic saline lake deposits to describe geochemical variability on Mars. Geophysical Research Letters 36: L19201.

Bandfield, J.L., 2008. High-silica deposits of an aqueous origin in western Hellas Basin, Mars. Geophysical Research Letters 35: L12205. doi: 10.1029/2008GL033807.

Banin, A., Clark, B.C. \& Wänke, H., 1992. Surface chemistry and mineralogy. In: Kieffer, H.H., Jakosky, B.M., Snyder, C.W. \& Matthews, M.S. (eds): Mars. University of Arizona Press (Tucson): 594-625.

Barnhart, C.J., Nimmo, F. \& Travis, B.J., 2010. Martian post-impact hydrothermal systems incorporating freezing. Icarus 208: 101-117.

Bell, J., McSween, H., Crisp, J., Morris, R., Murchie, S., Bridges, N., Johnson, J., Britt, D., Golombek, M., Moore, H., Ghosh, A., Bishop, J., Anderson, R., Bruckner, J., Economou, T., Greenwood, J., Gunnlaugsson, H., Hargraves, R., Hviid, S., Knudsen, J., Madsen, M., Reid, R., Rieder, R. \& Soderblom, L., 2000. Mineralogic and compositional properties of Martian soil and dust: results from Mars Pathfinder. Journal of Geophysical Research, Planets 105: 1721-1755.

Benison, K., 2006. A Martian analogue in Kansas: Comparing Martian strata with Permian acid saline lake deposits. Geology 34: 385-388.

Benison, K. \& Bowen, B., 2006. Acid saline lake systems give clues about past environments and the search for life on Mars. Icarus 183: 225-229.

Benison, K. \& Goldstein, R., 2001. Evaporites and siliciclastics of the Permian Nippewalla Group of Kansas, USA: A case for non-marine deposition in saline lakes and saline pans. Sedimentology 48: 165-188.

Benison, K.C., Bowen, B.B., Oboh-Ikuenobe, F.E., Jagniecki, E.A., LaClair, D.A., Story, S.L., Mormile, M.R. \& Hong, B., 2007. Sedimentology of acid saline lakes in southern Western Australia: Newly described processes and products of an extreme environment. Journal of Sedimentary Research 77: 366-388.

Bibring, J., Langevin, Y., Gendrin, A., Gondet, B., Poulet, F., Berthe, M., Soufflot, A., Arvidson, R., Mangold, N., Mustard, J., Drossart, P. \& OMEGA Team, 2005. Mars surface diversity as revealed by the 0MEGA/Mars Express observations. Science 307: 1576-1581.

Bibring, J., Langevin, Y., Mustard, J., Poulet, F., Arvidson, R., Gendrin, A., Gondet, B., Mangold, N., Pinet, P., Forget, F. \& OMEGA team, 2006. Global mineralogical and aqueous Mars history derived from OMEGA/Mars express data. Science 312: 400-404.

Bigham, J. \& Nordstrom, D.K., 2000. Iron and aluminum hydroxysulfates from acid sulfate waters. In: Alpers, C.N., Jambor, J.L. \& Nordstrom, D.K. (eds): Sulfate Minerals, Crystallography, Geochemistry and Environmental Significance. Reviews in Mineralogy and Geochemistry, volume 40. The Mineralogical Society of America (Virginia): 351-403.

Bishop, J.L., Parente, M., Weitz, C.M., Dobrea, E.Z.N., Roach, L.H., Murchie, S.L., McGuire, P.C., McKeown, N.K., Rossi, C.M., Brown, A.J., Calvin, W.M., Milliken, R. \& Mustard, J.F., 2009. Mineralogy of Juventae Chasma: sulfates 
in the light-toned mounds, mafic minerals in the bedrock, and hydrated silica and hydroxylated ferric sulfate on the plateau. Journal of Geophysical Research, Planets 114: E00D09. doi: 10.1029/2009JE003352.

Braitsch, O., 1971. Salt deposits, their origin and composition. Springer (New York): 297pp.

Bridges, J., Catling, D., Saxton, J., Swindle, T., Lyon, I. \& Grady, M., 2001. Alteration assemblages in Martian meteorites: Implications for near-surface processes. Space Science Reviews 96: 365-392.

Broz, P. \& Hauber, E., 2012. A unique volcanic field in Tharsis, Mars: pyroclastic cones as evidence for explosive eruptions. Icarus 218: 88-99.

Broz, P. \& Hauber, E., 2013. Hydrovolcanic tuff rings and cones as indicators for phreatomagmatic explosive eruptions on Mars. Journal of Geophysical Research 118: 1656-1675.

Brückner, J., Dreibus, G., Gellert, R., Squyres, S., Wanke, H., Yen, A. \& Zipfel, J., 2008. Mars Exploration Rovers: Chemical composition by the APXS. In: Bell, J. (ed.): The Martian Surface: Composition, Mineralogy, and Physical Properties. Cambridge University Press (Cambridge): 58-101.

Burgess, R., Cartwright, J.A. \& Filiberto, J., 2013. Halogen abundances of the Martian mantle. Goldschmidt 2013 (abstract). Mineralogical Magazine 77(5): 793.

Burns, R. \& Fisher, D., 1990. Evolution of sulphide mineralization on Mars. Journal of Geophysical Research, Solid Earth and Planets 95: 14169-14173.

Burns, R. \& Fisher, D., 1993. Rates of oxidative weathering on the surface of Mars. Journal of Geophysical Research, Planets 98: 3365-3372.

Carr, M.H. \& Head, , III, J.W., 2010. Geologic history of Mars. Earth and Planetary Science Letters 294: 185-203.

Carter, J. \& Poulet, F., 2012. Orbital identification of clays and carbonates in Gusev crater. Icarus 219: 250-253.

Chapman, M.G., 2002. Layered massive, and thin sediments on Mars: possible Late Noachian to Late Amazonian tephra? In: Smellie, J.L. \& Chapman, M.G. (eds): Volcano/Ice Interactions on Earth and Mars. Geological Society Special Publication No. 202: 273-293.

Chapman, M.G. \& Tanaka, K.L., 2001. Interior trough deposits on Mars: Subice volcanoes? Journal of Geophysical Research, Planets 106: 10087-10100.

Chevrier, V. \& Mathé, P.E., 2007. Mineralogy and evolution of the surface of Mars: a review. Planetary and Space Science 55: 289-314.

Chevrier, V., Rochette, P., Mathé, P. \& Grauby, 0., 2004. Weathering of iron-rich phases in simulated Martian atmospheres. Geology 32: 1033-1036.

Chevrier, V., Mathé, P.E., Rochette, P., Grauby, O., Bourrie, G. \& Trolard, $\boldsymbol{F} ., 2006$. Iron weathering products in a $\mathrm{CO} 2+(\mathrm{H} 2 \mathrm{O}$ or H202) atmosphere: Implications for weathering processes on the surface of Mars. Geochimica et Cosmochimica Acta 70: 4295-4317.

Christensen, P., Bandfield, J., Hamilton, V., Ruff, S., Kieffer, H., Titus, T., Malin, M., Morris, R., Lane, M., Clark, R., Jakosky, B., Mellon, M., Pearl, J., Conrath, B., Smith, M., Clancy, R., Kuzmin, R., Roush, T., Mehall, G., Gorelick, N., Bender, K., Murray, K., Dason, S., Greene, E., Silverman, S. \& Greenfield, M., 2001. Mars Global Surveyor Thermal Emission Spectrometer experiment: investigation description and surface science results. Journal of Geophysical Research, Planets 106: 23823-23871.

Christensen, P.R., Wyatt, M.B., Glotch, T.D., Rogers, A.D., Anwar, S., Arvidson, R.E., Bandfield, J.L., Blaney, D.L., Budney, C., Calvin, W.M., Faracaro, A., Fergason, R.L., Gorelick, N., Graff, T.G., Hamilton, V.E., Hayes, A.G., Johnson, J.R., Knudson, A.T., McSween, H.Y., Mehall, G.L., Mehall, L.K.,
Moersch, J.E., Morris, R.V., Smith, M.D., Squyres, S.W., Ruff, S.W. \& Wolff, M.J., 2004. Mineralogy at Meridiani Planum from the Mini-TES experiment on the Opportunity Rover. Science 306: 1733-1739.

Clark, B.C., Baird, A.K., Rose, H.J., Toulmin, P., Keil, K., Castro, A.J., Kelliher, W.C., Rowe, C.D. \& Evans, P.H., 1976. Inorganic analyses of Martian surface samples at the Viking landing sites. Science 194: 1283-1288.

Clark, B.C., Baird, A.K., Weldon, R.J., Tsusaki, D.M., Schnabel, L. \& Candelaria, M.P., 1982. Chemical composition of Martian fines. Journal of Geophysical Research: Solid Earth 87: 10059-10067.

Clark, B.C., Morris, R.V., McLennan, S.M., Gellert, R., Jolliff, B., Knoll, A.H., Squyres, S.W., Lowenstein, T.K., Ming, D.W., Tosca, N.J., Yen, A., Christensen, P.R., Gorevan, S., Bruckner, J., Calvin, W., Dreibus, G., Farrand, W., Klingelhöfer, G., Waenke, H., Zipfel, J., Bell, J.F., Grotzinger, J., McSween, H.Y. \& Rieder, R., 2005. Chemistry and mineralogy of outcrops at Meridiani Planum. Earth and Planetary Science Letters 240: 73-94.

Dehouck, E., Chevrier, V., Gaudin, A., Mangold, N., Mathe, P. \& Rochette, P., 2012. Evaluating the role of sulfide-weathering in the formation of sulfates or carbonates on Mars. Geochimica et Cosmochimica Acta 90: 47-63.

Delmelle, P. \& Bernard, A., 1994. Geochemistry, mineralogy and chemical modelling of the acid crater lake of Kawah-Ijen Volcano, Indonesia. Geochimica et Cosmochimica Acta 58: 2445-2460.

Delmelle, P., Bernard, A., Kusakabe, M., Fischer, T.P. \& Takano, B., 2000. Geochemistry of the magmatic-hydrothermal system of Kawah Ijen volcano, East Java, Indonesia. Journal of Volcanology and Geothermal Research 97: 31-53.

Dohm, J.M., Williams, J., Anderson, R.C., Ruiz, J., McGuire, P.C., Komatsu, G., Davila, A.F., Ferris, J.C., Schulze-Makuch, D., Baker, V.R., Boynton, W.V., Fairen, A.G., Hare, T.M., Miyamoto, H., Tanaka, K.L. \& Wheelock, S.J., 2009. New evidence for a magmatic influence on the origin of Valles Marineris, Mars. Journal of Volcanology and Geothermal Research 185: 12-27.

Dreibus, G. \& Wänke, H., 1987. Volatiles on Earth and Mars: a comparison. Icarus 71: 225-240.

Economou, T, 2001. Chemical analyses of Martian soil and rocks obtained by the Pathfinder Alpha Proton X-ray spectrometer. Radiation Physics and Chemistry 61: 191-197.

Ehlmann, B.L., Mustard, J.F., Murchie, S.L., Bibring, J., Meunier, A., Fraeman, A.A. \& Langevin, Y., 2011. Subsurface water and clay mineral formation during the early history of Mars. Nature 479: 53-60.

Einaudi, M.T., Hedenquist, J.W. \& Inan, E.E., 2003. Sulfidation State of Fluids in Active and Extinct Hydrothermal Systems: Transitions from Porphyry to Epithermal Environments. In: Simmons, S.F. \& Graham, I. (eds): Volcanic, Geothermal, and Ore-Forming Fluids: Rulers and Witnesses of Processes within the Earth. Society of Economic Geologists, Special Publication No. 10. Littleton (Colorado): 285-314.

Elwood-Madden, M., Bodnar, R. \& Rimstidt, J., 2004. Jarosite as an indicator of water-limited chemical weathering on Mars. Nature 431: 821-823.

Fairén, A., Fernández-Remolar, D., Dohm, J., Baker, V. \& Amils, R., 2004. Inhibition of carbonate synthesis in acidic oceans on early Mars. Nature 431: 423-426.

Fernández-Remolar, D. \& Knoll, A.H., 2008. Fossilization potential of ironbearing minerals in acidic environments of Rio Tinto, Spain: implications for Mars exploration. Icarus 194: 72-85. 
Fernández-Remolar, D., Morris, R., Gruener, J., Amils, R. \& Knoll, A., 2005. The Río Tinto basin, Spain: mineralogy, sedimentary geobiology and implications for interpretation of outcrop rocks at Meridiani Planum, Mars. Earth and Planetary Science Letters 240: 149-167.

Fernández-Remolar, D., Prieto-Ballesteros, 0., Gómez-Ortiz, D., FernándezSanpedro, M., Sarrazin, P., Gailhanou, M. \& Amils, R., 2011. Río Tinto sedimentary mineral assemblages: A terrestrial perspective that suggests some formation pathways of phyllosilicates on Mars. Icarus 211: 114-138.

Filiberto, J. \& Treiman, A.H., 2009. Martian magmas contained abundant chlorine, but little water. Geology 37: 1087-1090.

Filiberto, J., Chin, E., Day, J.M.D., Franchi, I.A., Greenwood, R.C., Gross, J., Penniston-Dorland, S.C., Schwenzer, S.P. \& Treiman, A.H., 2012. Geochemistry of intermediate olivine-phyric shergottite Northwest Africa 6234, with similarities to basaltic shergottite Northwest Africa 480 and olivine-phyric shergottite Northwest Africa 2990. Meteoritics \& Planetary Science 47: 12561273.

Fishbaugh, K.E., Poulet, F., Chevrier, V., Langevin, Y. \& Bibring, J.P., 2007. On the origin of gypsum in the Mars north polar region. Journal of Geophysical Research, Planets 112: E07002. doi: 10.1029/2006JE002862.

Flahaut, J., Quantin, C., Allemand, P., Thomas, P. \& Le Deit, L., 2010. Identification, distribution and possible origins of sulfates in Capri Chasma (Mars), inferred from CRISM data. Journal of Geophysical Research 115: E11007. doi: 10.1029/2009JE003566.

Flahaut, J., Quantin, C., Clenet, H., Allemand, P., Mustard, J.F. \& Thomas, P., 2012. Pristine Noachian crust and key geologic transitions in the lower walls of Valles Marineris: Insights into early igneous processes on Mars. Icarus 221: 420-435.

Foley, C., Economou, T. \& Clayton, R., 2003. Final chemical results from the Mars Pathfinder alpha proton X-ray spectrometer. Journal of Geophysical Research, Planets 108: 8095. doi: 10.1029/2002JE002018.

Fournier, R.O. \& Rowe, J.J., 1966. Estimation of underground temperatures from the silica content of water from hot springs and wet-steam wells. American Journal of Science 264: 685-697.

Fuenten, F., Flahaut, J., Stesky, R., Hauber, E. \& Rossi, A.P., 2014. Stratigraphy and mineralogy of Candor Mensa, West Candor Chasma, Mars: Insights into the geologic history of Valles Marineris. Journal of Geophysical Research, Planets 119: 331-354. doi: 10.1002/2013JE004557.

Gaillard, F., Michalski, J., Berger, G., McLennan, S.M. \& Scaillet, B., 2013. Geochemical reservoirs and timing of sulfur cycling on Mars. Space Science Reviews 174: 251-300.

Gammons, C.H., Wood, S.A., Pedrozo, F., Varekamp, J.C., Nelson, B.J., Shope, C.L. \& Baffico, G., 2005. Hydrogeochemistry and rare earth element behaviour in a volcanically acidified watershed in Patagonia, Argentina. Chemical Geology 222: 249-267.

Gellert, R., Rieder, R., Anderson, R., Bruckner, J., Clark, B.C., Dreibus, G., Economou, T., Klingelhofer, G., Lugmair, G., Ming, D., Squyres, S., d'Uston, C., Wanke, H., Yen, A. \& Zipfel, J., 2004. Chemistry of rocks and soils in Gusev crater from the alpha particle X-ray spectrometer. Science 305: 829-832.

Gellert, R., Rieder, R., Bruckner, J., Clark, B.C., Dreibus, G., Klingelhofer, G., Lugmair, G., Ming, D., Wanke, H., Yen, A., Zipfel, J. \& Squyres, S.W., 2006. Alpha particle X-ray spectrometer (APXS): results from Gusev crater and calibration report. Journal of Geophysical Research, Planets 111: E02S05.
Gendrin, A., Mangold, N., Bibring, J., Langevin, Y., Gondet, B., Poulet, F., Bonello, G., Quantin, C., Mustard, J., Arvidson, R. \& LeMouelic, S., 2005. Sulfates in Martian layered terrains: the OMEGA/Mars Express view. Science 307: 1587-1591.

Glotch, T.D. \& Bandfield, J.L., 2006. Determination and interpretation of surface and atmospheric Miniature Thermal Emission Spectrometer spectral endmembers at the Meridiani Planum landing site. Journal of Geophysical Research, Planets 111: E12S06.

Glotch, T.D., Bandfield, J.L., Christensen, P.R., Calvin, W.M., McLennan, S.M., Clark, B.C., Rogers, A.D. \& Squyres, S.W., 2006. Mineralogy of the lighttoned outcrop at Meridiani Planum as seen by the Miniature Thermal Emission Spectrometer and implications for its formation. Journal of Geophysical Research, Planets 111: E12S03.

Golden, D., Ming, D., Morris, R. \& Mertzman, S., 2005. Laboratory-simulated acid-sulfate weathering of basaltic materials: implications for formation of sulfates at Meridiani Planum and Gusev crater, Mars. Journal of Geophysical Research, Planets 110: E12S07. doi: 10.1029/2005JE002451.

Greenwood, J.P., 2005. Chlorine-rich apatites in SNC's: evidence for magma-brine interactions on Mars? 68th Annual Meteoritical Society Meeting. Abstract 349: 285-293.

Grindrod, P.M. \& Balme, M.R., 2010. Groundwater processes in Hebes Chasma, Mars. Geophysical Research Letters 37: L13202. doi: 10.1029/2010GL044122.

Gross, J., Filiberto, J. \& Bell, A.S., 2013. Water in the Martian interior: evidence for terrestrial MORB mantle-like volatile contents from hydroxyl-rich apatite in olivine-phyric shergottite NWA 6234. Earth and Planetary Science Letters 369-370: 120-128.

Grott, M., Baratoux, D., Hauber, E., Sautter, V., Mustard, J., Gasnault, 0., Ruff, S.W., Karato, S., Debaille, V., Knapmeyer, M., Sohl, F., van Hoolst, T., Breuer, D., Morschhauser, A. \& Toplis, M.J., 2013. Long-term evolution of the Martian crust-mantle system. Space Science Reviews 174: 49-111.

Grotzinger, J., Arvidson, R., Bell, J., Calvin, W., Clark, B., Fike, D., Golombek, M., Greeley, R., Haldemann, A., Herkenhoff, K., Jolliff, B., Knoll, A., Malin, M., McLennan, S., Parker, T., Soderblom, L., Sohl-Dickstein, J., Squyres, S., Tosca, N. \& Watters, W., 2005. Stratigraphy and sedimentology of a dry to wet eolian depositional system, Burns formation, Meridiani Planum, Mars. Earth and Planetary Science Letters 240: 11-72.

Hanley, J., Chevrier, V.F., Berget, D.J. \& Adams, R.D., 2012. Chlorate salts and solutions on Mars. Geophysical Research Letters 39: L08201.

Haskin, L., Wang, A., Jolliff, B., McSween, H., Clark, B., Des Marais, D., McLennan, S., Tosca, N., Hurowitz, J., Farmer, J., Yen, A., Squyres, S., Arvidson, R., Klingelhofer, G., Schroder, C., de Souza, P., Ming, D., Gellert, R., Zipfel, J., Bruckner, J., Bell, J., Herkenhoff, K., Christensen, P., Ruff, S., Blaney, D., Gorevan, S., Cabrol, N., Crumpler, L., Grant, J. \& Soderblom, L., 2005. Water alteration of rocks and soils on Mars at the Spirit rover site in Gusev crater. Nature 436: 66-69.

Hauber, E., Broz, P., Jagert, F., Jodlowski, P. \& Platz, T., 2011. Very recent and wide-spread basaltic volcanism on Mars. Geophysical Research Letters 38: L10201.

Hausrath, E.M., Golden, D.C., Morris, R.V., Agresti, D.G. \& Ming, D.W., 2013. Acid sulfate alteration of fluorapatite, basaltic glass and olivine by hydrothermal vapours and fluids: implications for fumarolic activity and secondary phosphate phases in sulfate-rich Paso Robles soil at Gusev crater, Mars. Journal of Geophysical Research, Planets 118: 1-13. doi: 10.1029/2012JE004246. 
Heald, P., Foley, N.K. \& Hayba, D.O., 1987. Comparative anatomy of volcanichosted epithermal deposits: acid-sulfate and adularia-sericite. Economic Geology 82: 1-26.

Henley, R.W. \& Ellis, A.J., 1983. Geothermal systems ancient and modern, a geochemical review. Earth Science Reviews 19: 1-50.

Hodges, C. \& Moore, H., 1994. Atlas of Volcanic Landforms on Mars. US Geological Survey (Washington): $194 \mathrm{pp}$.

Horgan, B.H., Bell, J.F. III, Dobrea, E.Z.N., Cloutis, E.A., Bailey, D.T., Craig, M.A., Roach, L.H. \& Mustard, J.F., 2009. Distribution of hydrated minerals in the north polar region of Mars. Journal of Geophysical Research, Planets 114: E01005. doi:10.1029/2008JE003187.

Hynek, B.M., Phillips, R.J. \& Arvidson, R.E., 2003. Explosive volcanism in the Tharsis region: global evidence in the Martian record. Journal of Geophysical Research 108(E9): 5111. doi: 10.1029/2003JE002062.

Hynek, B.M., McCollom, T.M., Marcucci, E.C., Brugman, K. \& Rogers, K.L., 2013. Assessment of environmental controls on acid-sulfate alteration at active volcanoes in Nicaragua: applications to relic hydrothermal systems on Mars. Journal of Geophysical Research, Planets 118: 2083-2104.

Johnson, J.R., Bell, J.F. III, Cloutis, E., Staid, M., Farrand, W.H., McCoy, T., Rice, M., Wang, A. \& Yen, A., 2007. Mineralogic constraints on sulfur-rich soils from Pancam spectra at Gusev crater, Mars. Geophysical Research Letters 34: L13202.

Keller, J.M., Boynton, W.V., Karunatillake, S., Baker, V.R., Dohm, J.M., Evans, L.G., Finch, M.J., Hahn, B.C., Hamara, D.K., Janes, D.M., Kerry, K.E., Newsom, H.E., Reedy, R.C., Sprague, A.L., Squyres, S.W., Starr, R.D., Taylor, G.J. \& Williams, R.M.S., 2006. Equatorial and mid-latitude distribution of chlorine measured by Mars Odyssey GRS. Journal of Geophysical Research, Planets 111: E03S08.

Kempter, K.A. \& Rowe, G.L., 2000. Leakage of active crater lake brine through the north flank at Rincón de la Vieja volcano, northwest Costa Rica, and implications for crater collapse. Journal of Volcanology and Geothermal Research 97: 143-159.

King, P.L. \& McLennan, S.M., 2010. Sulfur on Mars. Elements 6: 107-112.

King, H.E., Plumper, O., Geisler, T. \& Putnis, A., 2011. Experimental investigations into the silicification of olivine: implications for the reaction mechanism and acid neutralization. American Mineralogist 96: 1503-1511.

Kite, E.S., Lucas, A. \& Fassett, C.I., 2013. Pacing early Mars river activity: embedded craters in the Aeolis Dorsa region imply river activity spanned greater than or similar to (1-20) Myr. Icarus 225: 850-855.

Klingelhöfer, G., Morris, R., Bernhardt, B., Schroder, C., Rodionov, D., de Souza, P., Yen, A., Gellert, R., Evlanov, E., Zubkov, B., Foh, J., Bonnes, U., Kankeleit, E., Gutlich, P., Ming, D., Renz, F., Wdowiak, T., Squyres,

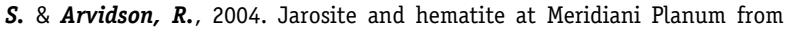
Opportunity's Mossbauer spectrometer. Science 306: 1740-1745.

Knauth, L., Burt, D. \& Wohletz, K., 2005. Impact origin of sediments at the Opportunity landing site on Mars. Nature 438: 1123-1128.

Komatsu, G., Geissler, P.E., Strom, R.G. \& Singer, R.B.. 1993. Stratigraphy and erosional landforms of layered deposits in Valles Marineris, Mars. Journal of Geophysical Research, Planets 98: 11105-11121.

Komatsu, G., Ori, G.G., Ciarcelluti, P. \& Litasov, Y.D., 2004. Interior layered deposits of Valles Marineris, Mars: analogous subice volcanism related to Baikal Rifting, Southern Siberia. Planetary Space Science 52: 167-187.
Kounaves, S.P., Carrier, B.L., O'Neil, G.D., Stroble, S.T. \& Claire, M.W., 2014. Evidence of Martian perchlorate, chlorate, and nitrate in Mars meteorite EETA79001: Implications for oxidants and organics. Icarus 229: 206-213.

Kusakabe, M., Komoda, Y., Takano, B. \& Abiko, T., 2000. Sulfur isotopic effects in the disproportionation reaction of sulfur dioxide in hydrothermal fluids: implications for the delta S-34 variations of dissolved bisulfate and elemental sulfur from active crater lakes. Journal of Volcanology and Geothermal Research 97: 287-307.

Langevin, Y., Poulet, F., Bibring, J. \& Gondet, B., 2005. Sulfates in the north polar region of Mars detected by OMEGA/Mars express. Science 307: 15841586.

Lewis, K.W., Aharonson, O., Grotzinger, J.P., Squyres, S.W., Bell, J.F. III, Crumpler, L.S. \& Schmidt, M.E., 2008. Structure and stratigraphy of Home Plate from the Spirit Mars Exploration Rover. Journal of Geophysical Research, Planets 113: E12S36.

Lodders, K., 1998. A survey of shergottite, nakhlite and chassigny meteorites whole-rock compositions. Meteoritics \& Planetary Science 33: A183-A190.

Lodders, K. \& Fegley, B., 1997. An oxygen isotope model for the composition of Mars. Icarus 126: 373-394.

Lorand, J.P., Chevrier, V. \& Sautter, V., 2005. Sulfide mineralogy and redox conditions in some shergottites. Meteoritics \& Planetary Science 40: 12571252.

Lucchitta, B.K., 1987. Valles Marineris, Mars: wet debris flows and ground ice. Icarus 72: 411-429.

Lucchitta, B.K., 1990. Young volcanic deposits in the Valles Marineris, Mars? Icarus 86: 476-509.

Lucchitta, B.K., Isbell, N.K. \& Howington-Kraus, A., 1994. Topography of Valles Marineris: Implications for erosional and structural history. Journal of Geophysical Research, Planets 99: 3783-3798.

Mangold, N., Gendrin, A., Gondet, B., LeMouelic, S., Quantin, C., Ansan, V., Bibring, J., Langevin, Y., Masson, P. \& Neukum, G., 2008. Spectral and geological study of the sulfate-rich region of West Candor Chasma, Mars. Icarus 194: 519-543.

Marcucci, E.C. \& Hynek, B.M., 2014. Laboratory simulations of acid-sulfate weathering under volcanic hydrothermal conditions: implications for early Mars. Journal of Geophysical Research, Planets 119: 679-703.

Marcucci, E.C., Hynek, B.M., Kierein-Young, K.S. \& Rogers, K.L., 2013. Visiblenear-infrared reflectance spectroscopy of volcanic acid-sulfate alteration in Nicaragua: analogs for early Mars. Journal of Geophysical Research, Planets 118: 2213-2233.

Marion, G.M., Catling, D.C., Zahnle, K.J. \& Claire, M.W., 2010. Modeling aqueous perchlorate chemistries with applications to Mars. Icarus 207: 675-685.

Martínez, M., 2008. Geochemical evolution of the acid crater lake of Poás volcano (Costa Rica): insights into volcanic-hydrothermal processes. PhD thesis, Utrecht University: $161 \mathrm{pp}$.

Massé, M., Bourgeois, O., Le Mouélic, S., Verpoorter, C., Le Deit, L. and Bibring, J.P., 2010. Martian polar and circum-polar sulfate-bearing deposits: sublimation tills derived from the North Polar Cap. Icarus 209: 434-451.

McCauley, J.F., 1978. Geological map of the Coprates quadrangle of Mars. US Geological Survey Map, I-897, scale 1:5,000,000.

McCollom, T.M. \& Hynek, B.M., 2005. A volcanic environment for bedrock diagenesis at Meridiani Planum on Mars. Nature 438: 1129-1131. 
McCollom, T.M., Hynek, B.M., Rogers, K., Moskowitz, B. \& Berquo, T.S., 2013. Chemical and mineralogical trends during acid-sulfate alteration of pyroclastic basalt at Cerro Negro volcano and implications for early Mars. Journal of Geophysical Research, Planets 118: 1719-1751.

McLennan, S.M., Bell, J.F., Calvin, W.M., Christensen, P.R., Clark, B C., de Souza, P.A., Farmer, J., Farrand, W.H., Fike, D.A., Gellert, R., Ghosh, A., Glotch, T.D., Grotzinger, J.P., Hahn, B., Herkenhoff, K.E., Hurowitz, J.A., Johnson, J.R., Johnson, S.S., Jolliff, B., Klingelhofer, G., Knoll, A.H., Learner, Z., Malin, M.C., McSween, H.Y., Pocock, J., Ruff, S.W., Soderblom, L.A., Squyres, S.W., Tosca, N.J., Watters, W.A., Wyatt, M.B. \& Yen, A., 2005. Provenance and diagenesis of the evaporite-bearing Burns formation, Meridiani Planum, Mars. Earth and Planetary Science Letters 240: 95-121.

McLennan, S.M., Anderson, R.B., Bell, J.F. III, Bridges, J.C., Calef, F. III, Campbell, J.L., Clark, B.C., Clegg, S., Conrad, P., Cousin, A., Des Marais, D.J., Dromart, G., Dyar, M.D., Edgar, L.A., Ehlmann, B.L., Fabre, C., Forni, O., Gasnault, 0., Gellert, R., Gordon, S., Grant, J.A., Grotzinger, J.P., Gupta, S., Herkenhoff, K.E., Hurowitz, J.A., King, P.L., Le Mouelic, S., Leshin, L.A., Leveille, R., Lewis, K.W., Mangold, N., Maurice, S., Ming, D.W., Morris, R.V., Nachon, M., Newsom, H.E., Ollila, A.M., Perrett, G.M., Rice, M.S., Schmidt, M.E., Schwenzer, S.P., Stack, K., Stolper, , Stolper, E.M., Sumner, D.Y., Treiman, A.H., van Bommel, S., Vaniman, D.T., Vasavada, A., Wiens, R.C., Yingst, R.A. \& MSL Sci Team, 2014. Elemental Geochemistry of Sedimentary Rocks at Yellowknife Bay, Gale Crater, Mars. Science 343: 1244734.

McSween, H., Wyatt, M., Gellert, R., Bell, J., Morris, R., Herkenhoff, K., Crumpler, L., Milam, K., Stockstill, K., Tornabene, L., Arvidson, R., Bartlett, P., Blaney, D., Cabrol, N., Christensen, P., Clark, B., Crisp, J., Des Marais, D., Economou, T., Farmer, J., Farrand, W., Ghosh, A., Golombek, M., Gorevan, S., Greeley, R., Hamilton, V., Johnson, J., Joliff, B., Klingelhofer, G., Knudson, A., McLennan, S., Ming, D., Moersch, J., Rieder, R., Ruff, S., Schroder, C., de Souza, P., Squyres, S., Wanke, H., Wang, A., Yen, A. \& Zipfel, J., 2006. Characterization and petrologic interpretation of olivine-rich basalts at Gusev crater, Mars. Journal of Geophysical Research, Planets 111: E02S10.

McSween, H.Y., Ruff, S.W., Morris, R.V., Gellert, R., Klingelhöfer, G., Christensen, P.R., McCoy, T.J., Ghosh, A., Moersch, J.M., Cohen, B.A., Rogers, A.D., Schroeder, C., Squyres, S.W., Crisp, J. \& Yen, A., 2008. Mineralogy of volcanic rocks in Gusev crater, Mars: reconciling Mossbauer, Alpha Particle X-ray Spectrometer, and Miniature Thermal Emission Spectrometer spectra. Journal of Geophysical Research, Planets 113: E06S04.

Metz, J.M., Grotzinger, J.P., Mohrig, D., Milliken, R., Prather, B., Pirmez, C., McEwen, A.S. \& Weitz, C.M., 2009. Sublacustrine depositional fans in southwest Melas Chasma. Journal of Geophysical Research, Planets 114: E10002.

Milliken, R.E., Swayze, G.A., Arvidson, R.E., Bishop, J.L., Clark, R.N., Ehlmann, B.L., Green, R.O., Grotzinger, J.P., Morris, R.V., Murchie, S.L., Mustard, J.F. \& Weitz, C., 2008. Opaline silica in young deposits on Mars. Geology 36: 847-850.

Milliken, R.E., Grotzinger, J.P. \& Thomson, B.J., 2010. Paleoclimate of Mars as captured by the stratigraphic record in Gale Crater. Geophysical Research Letters 37: L04201.

Ming, D. , Mittlefehldt, D., Morris, R., Golden, D., Gellert, R., Yen, A., Clark, B., Squyres, S., Farrand, W., Ruff, S., Arvidson, R., Klingelhofer, G., McSween, H., Rodionov, D., Schroder, C., de Souza, P. \& Wang, A., 2006. Geochemical and mineralogical indicators for aqueous processes in the Columbia Hills of Gusev crater, Mars. Journal of Geophysical Research, Planets 111: E02S12.

Ming, D.W., Morris, R.V. \& Clark, B.C., 2008. Aqueous alteration on Mars. In: Bell, J. (ed.): The Martian surface: composition, mineralogy and physical properties. Cambridge University Press (Cambridge): 519-540.

Morris, R., Klingelhöfer, G., Bernhardt, B., Schroder, C., Rodionov, D., de Souza, P., Yen, A., Gellert, R., Evlanov, E., Foh, J., Kankeleit, E., Gutlich, P., Ming, D., Renz, F., Wdowiak, T., Squyres, S. \& Arvidson, R., 2004. Mineralogy at Gusev crater from the Mossbauer spectrometer on the Spirit rover. Science 305: 833-836.

Morris, R., Klingelhöfer, G., Schroder, C., Rodionov, D., Yen, A., Ming, D., de Souza, P., Fleischer, I., Wdowiak, T., Gellert, R., Bernhardt, B., Evlanov, E., Zubkov, B., Foh, J., Bonnes, U., Kankeleit, E., Gutlich, P., Renz, F., Squyres, S. \& Arvidson, R., 2006. Mossbauer mineralogy of rock, soil, and dust at Gusev crater, Mars: Spirit's journey through weakly altered olivine basalt on the plains and pervasively altered basalt in the Columbia Hills. Journal of Geophysical Research, Planets 111: E02S13.

Musselwhite, D.S., Dalton, H.A., Kiefer, W.S. \& Treiman, A.H., 2006. Experimental petrology of the basaltic shergottite Yamato-980459: implications for the thermal structure of the Martian mantle. Meteoritics \& Planetary Science 41: 1271-1290.

Mustard, J.F., Murchie, S.L., Pelkey, S.M., Ehlmann, B.L., Milliken, R.E., Grant, J.A., Bibring, J., Poulet, F., Bishop, J., Dobrea, E.N., Roach, L., Seelos, F., Arvidson, R.E., Wiseman, S., Green, R., Hash, C., Humm, D., Malaret, E., McGovern, J.A., Seelos, K., Clancy, T., Clark, R., Des Marais, D., Izenberg, N., Knudson, A., Langevin, Y., Martin, T., McGuire, P., Morris, R., Robinson, M., Roush, T., Smith, M., Swayze, G., Taylor, H., Titus, T. \& Wolff, M., 2008. Hydrated silicate minerals on mars observed by the Mars Reconnaissance Orbiter CRISM instrument. Nature 454: 305-309.

Nedell, S.S., Squyres, S.W. \& Andersen, D.W., 1987. Origin and evolution of the layered deposits in the Valles Marineris, Mars. Icarus 70: 409-441.

Neukum, G., Jaumann, R., Hoffmann, H., Hauber, E., Head, J., Basilevsky, A., Ivanov, B., Werner, S., van Gasselt, S., Murray, J., McCord, T. \& HRSC Co-investigator Team, 2004. Recent and episodic volcanic and glacial activity on Mars revealed by the High Resolution Stereo Camera. Nature 432: 971-979.

Niles, P.B. \& Michalski, J., 2009. Meridiani Planum sediments on Mars formed through weathering in massive ice deposits. Nature Geoscience 2: 215-220.

Nordstrom, D.K. \& Alpers, C.N., 1999. Negative pH, efflorescent mineralogy, and consequences for environmental restoration at the Iron Mountain Superfund site, California. Proceedings of the National Academy of Sciences of the United States of America 96: 3455-3462.

Nordstrom, D.K, Alpers, C.N., Ptacek, C. \& Blowes, D., 2000. Negative pH and extremely acidic mine waters from Iron Mountain, California. Environmental Science \& Technology 34: 254-258.

Parkhurst, D.L. \& Appelo, C.A.J., 1999. User's guide to PHREEQC (Version 2), a computer program for speciation, batch-reaction, one-dimensional transport, and inverse geochemical calculations. USGS Report 99-4259 (Denver): 312 pp.

Pasternack, G.B. \& Varekamp, J.C., 1997. Volcanic lake systematics I. Physical constraints. Bulletin of Volcanology 58: 528-538.

Peterson, C., 1981. A secondary origin for the central plateau of Hebes Chasma. Lunar and Planetary Science Conference XI: 1459-1471. 
Rao, M.N., Bogard, D.D., Nyquist, L.E., McKay, D.S. \& Masarik, J., 2002. Neutron capture isotopes in the Martian regolith and implications for Martian atmospheric noble gases. Icarus 156: 352-372.

Rieder, R., Wanke, H., Economou, T. and Turkevich, A., 1997. Determination of the chemical composition of Martian soil and rocks: The alpha proton X-ray spectrometer. Journal of Geophysical Research, Planets 102: 40274044.

Rieder, R., Gellert, R., Anderson, R., Bruckner, J., Clark, B., Dreibus, G., Economou, T., Klingelhöfer, G., Lugmair, G., Ming, D., Squyres, S. , d'Uston, C., Wanke, H., Yen, A. \& Zipfel, J., 2004. Chemistry of rocks and soils at Meridiani Planum from the alpha particle X-ray spectrometer. Science 306: 1746-1749.

Roach, L.H., Mustard, J.F., Murchie, S.L., Bibring, J., Forget, F., Lewis, K.W., Aharonson, O., Vincendon, M. \& Bishop, J.L.., 2009. Testing evidence of recent hydration state change in sulfates on Mars. Journal of Geophysical Research,-Planets 114: E00D02.

Robbins, S.J., Di Achille, G. \& Hynek, B.M., 2011. The volcanic history of Mars: high-resolution crater-based studies of the calderas of 20 volcanoes. Icarus 211: 1179-1203.

Rossi, A.P., Neukum, G., Pondrelli, M., van Gasselt, S., Zegers, T., Hauber, E., Chicarro, A. \& Foing, B., 2008. Large-scale spring deposits on Mars? Journal of Geophysical Research, Planets 113: E08016. doi: 10.1029/2007JE003062.

Rowe, G.L., Brantley, S.L., Fernández, M., Fernández, J.F., Borgia, A. \& Barquero, J., 1992. Fluid-volcano interaction in an active stratovolcano: the crater lake system of Poás volcano, Costa Rica. Journal of Volcanology and Geothermal Research 49: 23-51.

Ruff, S.W., Farmer, J.D., Calvin, W.M., Herkenhoff, K.E., Johnson, J.R., Morris, R.V., Rice, M.S., Arvidson, R.E., Bell, J.F. III, Christensen, P.R. \& Squyres, $S . W ., 2011$. Characteristics, distribution, origin, and significance of opaline silica observed by the Spirit rover in Gusev crater, Mars. Journal of Geophysical Research, Planets 116: E00F23.

Ruff, S.W., Niles, P.B., Alfano, F. \& Clarke, A.B., 2014. Evidence for a Noachianaged ephemeral lake in Gusev crater, Mars. Geology 42: 359-362.

Scher, S., Williams-Jones, A.E. \& Williams-Jones, G., 2013. Fumarolic activity, acid-sulfate alteration, and high sulfidation epithermal precious metal mineralization in the crater of Kawah Ijen Volcano, Java, Indonesia. Economic Geology 108: 1099-1118.

Schmidt, M.E., Ruff, S.W., McCoy, T.J., Farrand, W.H., Johnson, J.R., Gellert, R., Ming, D.W., Morris, R.V., Cabrol, N., Lewis, K.W. \& Schroeder, C., 2008. Hydrothermal origin of halogens at Home Plate, Gusev Crater. Journal of Geophysical Research, Planets 113: E06S12.

Schwenzer, S.P., Abramov, O., Allen, C.C., Bridges, J.C., Clifford, S.M., Filiberto, J., Kring, D.A., Lasue, J., McGovern, P.J., Newsom, H.E., Treiman, A.H., Vaniman, D.T., Wiens, R.C. \& Wittmann, A., 2012. Gale Crater: Formation and post-impact hydrous environments. Planetary and Space Science 70: 84-95.

Sefton-Nash, E. \& Catling, D.C., 2008. Hematitic concretions at Meridiani Planum, Mars: Their growth timescale and possible relationship with iron sulfates. Earth and Planetary Science Letters 269: 365-375.

Sefton-Nash, E., Catling, D.C., Wood, S.E., Grindrod, P.M. \& Teanby, N.A., 2012. Topographic, spectral and thermal inertia analysis of interior layered deposits in Iani Chaos, Mars. Icarus 221: 20-42.
Skok, J.R., Mustard, J.F., Ehlmann, B.L., Milliken, R.E. \& Murchie, S.L., 2010. Silica deposits in the Nili Patera caldera on the Syrtis Major volcanic complex on Mars. Nature Geoscience 3: 838-841.

Squyres, S.W. \& Knoll, A.H., 2005. Sedimentary rocks at Meridiani Planum: origin, diagenesis, and implications for life on Mars. Earth and Planetary Science Letters 240: 1-10.

Squyres, S.W., Grotzinger, J.P., Arvidson, R.E., Bell, J.F., Calvin, W., Christensen, P.R., Clark, B.C., Crisp, J.A., Farrand, W.H., Herkenhoff, K.E., Johnson, J.R., Klingelhofer, G., Knoll, A.H., McLennan, S.M., McSween, H.Y., Morris, R.V., Rice, J.W., Rieder, R. \& Soderblom, L.A., 2004. In situ evidence for an ancient aqueous environment at Meridiani Planum, Mars. Science 306: 1709-1714.

Squyres, S.W., Aharonson, O., Clark, B.C., Cohen, B.A., Crumpler, L., de Souza, P.A., Farrand, W.H., Gellert, R., Grant, J., Grotzinger, J.P., Haldemann, A.F.C., Johnson, J.R., Klingelhöfer, G., Lewis, K.W., Li, R., McCoy, T., McEwen, A.S., McSween, H.Y., Ming, D.W., Moore, J.M., Morris, R.V., Parker, T.J., Rice, J.W. Jr., Ruff, S., Schmidt, M., Schroeder, C., Soderblom, L.A. \& Yen, A., 2007. Pyroclastic activity at Home Plate in Gusev crater, Mars. Science 316: 738-742.

Squyres, S.W., Arvidson, R.E., Ruff, S., Gellert, R., Morris, R.V., Ming, D.W., Crumpler, L., Farmer, J.D., Des Marais, D.J., Yen, A., McLennan, S.M., Calvin, W., Bell, J.F. III, Clark, B.C., Wang, A., McCoy, T.J., Schmidt, M.E. \& de Souza, P.A. Jr., 2008. Detection of silica-rich deposits on Mars. Science 320: 1063-1067.

Steiner, A., 1977. The Wairakei geothermal area, North Island, New Zealand. New Zealand Geological Survey Bulletin 90: 136.

Story, S., Bowen, B.B., Benison, K.C. \& Schulze, D.G., 2010. Authigenic phyllosilicates in modern acid saline lake sediments and implications for Mars. Journal of Geophysical Research, Planets 115: E12012.

Sutton, S.R., Rao, M.N., Dreibus, G., McKay, D.S., Wänke, H., Wentworth, S., Newville, M., Trainor, T. \& Flynn, G.J., 2001. Chlorine/bromine ratios in fracture-filling aqueous alteration products in Nakhla olivine. Lunar and Planetary Science Conference XXXIII, paper 1278.

Symonds, R.B. \& Reed, M.H., 1993. Calculation of multicomponent chemical equilibria in gas-solid-liquid systems: Calculation methods, thermochemical data and applications to studies of high-temperature volcanic gases with examples from Mount St Helens. American Journal of Science 293: 758-864.

Symonds, R.B., Gerlach, T.M. \& Reed, M.H., 2001. Magmatic gas scrubbing: implications for volcano monitoring. Journal of Volcanology and Geothermal Research 108: 303-341.

Tanaka, K.L., Scott, D.H. \& Greeley, R., 1992. Global Stratigraphy. In: Kieffer, H.H., Jakosky, B.M., Synder, C.W. \& Matthews, M.S. (eds): Mars. University of Arizona Press (Tucson): 345-382.

Taylor, G.J., Boynton, W.V., McLennan, S.M. \& Martel, L.M.V., 2010. K and $\mathrm{Cl}$ concentrations on the Martian surface determined by the Mars Odyssey Gamma Ray Spectrometer: implications for bulk halogen abundances in Mars. Geophysical Research Letters 37: L12204.

Thollot, P., Mangold, N., Ansan, V., Le Mouelic, S., Milliken, R.E., Bishop, J.L., Weitz, C.M., Roach, L.H., Mustard, J.F. \& Murchie, S.L., 2012. Most Mars minerals in a nutshell: various alteration phases formed in a single environment in Noctis Labyrinthus. Journal of Geophysical Research, Planets 117: E00J06. 
Thomson, B.J., Bridges, N.T., Milliken, R., Baldridge, A., Hook, S.J., Crowley, J.K., Marion, G.M., de Souza Filho, C.R., Brown, A.J. \& Weitz, C.M., 2011. Constraints on the origin and evolution of the layered mound in Gale Crater, Mars using Mars Reconnaissance Orbiter data. Icarus 214: 413-432.

Tosca, N.J. \& McLennan, S.M., 2006. Chemical divides and evaporite assemblages on Mars. Earth and Planetary Science Letters 241: 21-31.

Tosca, N.J., McLennan, S.M., Lindsley, D.H. \& Schoonen, M.A.A., 2004. Acidsulfate weathering of synthetic Martian basalt: the acid fog model revisited. Journal of Geophysical Research 109: E05003. doi: 10.1029/2003JE002218.

Tosca, N.J., McLennan, S.M., Clark, B.C., Grotzinger, J.P., Hurowitz, J.A., Knoll, A.H., Schroder, C. \& Squyres, S.W., 2005. Geochemical modeling of evaporation processes on Mars: insight from the sedimentary record at Meridiani Planum. Earth and Planetary Science Letters 240: 122-148.

Toulmin, P., Clark, B., Baird, A., Keil, K. \& Rose, H., 1976. Preliminary results from Viking X-ray fluorescence experiment, 1st sample from Chryse Planitia, Mars. Science 194: 81-84.

van Hinsberg, V., Berlo, K., van Bergen, M. \& Williams-Jones, A., 2010. Extreme alteration by hyperacidic brines at Kawah Ijen volcano, East Java, Indonesia: I. Textural and mineralogical imprint. Journal of Volcanology and Geothermal Research 198: 253-263.

Vaniman, D., Bish, D., Chipera, S., Fialips, C., Carey, J. \& Feldman, W., 2004. Magnesium sulphate salts and the history of water on Mars. Nature 431: 663-665.

Varekamp, J.C., 2008. The volcanic acidification of glacial Lake Caviahue, province of Neuquén, Argentina. Journal of Volcanology and Geothermal Research 178: 184-196.

Varekamp, J.C., Pasternack, G.B. \& Rowe, G.L., 2000. Volcanic lake systematics II. Chemical constraints. Journal of Volcanology and Geothermal Research 97: 161-179.

Varekamp, J.C., Ouimette, A.P., Herman, S.W., Flynn, K.S., Bermúdez, A. \& Delpino, D., 2009. Naturally acid waters from Copahue volcano, Argentina. Applied Geochemistry 24: 1354-1354.

Vaucher, J., Baratoux, D., Mangold, N., Pinet, P., Kurita, K. \& Gregoire, M., 2009. The volcanic history of central Elysium Planitia: implications for Martian magmatism. Icarus 204: 418-442.

Wang, A., Haskin, L., Squyres, S., Jolliff, B., Crumpler, L., Gellert, R., Schroder, C., Herkenhoff, K., Hurowitz, J., Tosca, N., Farrand, W., Anderson, R. \& Knudson, A., 2006. Sulfate deposition in subsurface regolith in Gusev crater, Mars. Journal of Geophysical Research, Planets 111: E02S17.

Wang, A., Bell, J.F., Li, R., Johnson, J.R., Farrand, W.H., Cloutis, E.A. Arvidson, R.E., Crumpler, L., Squyres, S.W., McLennan, S.M., Herkenhoff, K.E., Ruff, S.W., Knudson, A.T., Chen, W. \& Greenberger, R., 2008. Lighttoned salty soils and coexisting Si-rich species discovered by the Mars Exploration Rover Spirit in Columbia Hills. Journal of Geophysical Research, Planets 113: E12S40.
Weitz, C.M., Milliken, R.E., Grant, J.A., McEwen, A.S., Williams, R.M.E., Bishop J.L. \& Thomson, B.J., 2010. Mars Reconnaissance Orbiter observations of light-toned layered deposits and associated fluvial landforms on the plateaus adjacent to Valles Marineris. Icarus 205: 73-102.

Weitz, C.M., Bishop, J.L., Thollot, P., Mangold, N. \& Roach, L.H., 2011. Diverse mineralogies in two troughs of Noctis Labyrinthus, Mars. Geology 39: 899-902.

Wendt, L., Gross, C., Kneissl, T., Sowe, M., Combe, J.P., Le Deit, L., McGuire, P. \& Neukum, G., 2011. Sulfates and iron oxides in Ophir Chasma, Mars, based on OMEGA and CRISM observations. Icarus 213: 86-103.

Werner, S.C., 2009. The global Martian volcanic evolutionary history. Icarus 201: 44-68.

Williams, D.A., Greeley, R., Fergason, R.L., Kuzmin, R., McCord, T.B., Combe, J., Head, J.W. III, Xiao, L., Manfredi, L., Poulet, F., Pinet, P., Baratoux, D., Plaut, J.J., Raitala, J., Neukum, G. \& HRSC Co-Investigator Team, 2009. The Circum-Hellas volcanic province, Mars: overview. Planetary and Space Science 57: 895-916.

Wilson, L. \& Head, J.W., 1994. Mars, review and analysis of volcanic-eruption theory and relationships to observed landforms. Reviews of Geophysics 32: 221-263.

Wilson, L., Scott, E.D. \& Head, J.W., 2001. Evidence for episodicity in the magma supply to the large Tharsis volcanoes. Journal of Geophysical Research, Planets 106: 1423-1433.

Wray, J.J., 2013. Gale crater: The Mars Science Laboratory/Curiosity Rover Landing Site. International Journal of Astrobiology 12: 25-38.

Xiao, L., Huang, J., Christensen, P.R., Greeley, R., Williams, D.A., Zhao, J. \& $H e$, Q., 2012. Ancient volcanism and its implication for thermal evolution of Mars. Earth and Planetary Science Letters 323: 9-18.

Yen, A.S., Morris, R.V., Clark, B.C., Gellert, R., Knudson, A.T., Squyres, S., Mittlefehldt, D.W., Ming, D.W., Arvidson, R., McCoy, T., Schmidt, M., Hurowitz, J., Li, R. \& Johnson, J.R., 2008. Hydrothermal processes at Gusev crater: an evaluation of Paso Robles class soils. Journal of Geophysical Research, Planets 113: E06S10.

Zhao, Y.S., McLennan, S.M. \& Schoonen, M.A.A., 2014. Behavior of bromide, chloride, and phosphate during low-temperature aqueous $\mathrm{Fe}(\mathrm{II})$ oxidation processes on Mars. Journal of Geophysical Research, Planets 119: 998-1012. doi:10.1002/2013JE004417.

Zimbelman, D.R., Rye, R.O. \& Breit, G.N., 2005. Origin of secondary sulfate minerals on active andesitic stratovolcanoes. Chemical Geology 215: 37-60.

Zolotov, M.Y. \& Mironenko, M.V., 2007. Timing of acid weathering on Mars: a kinetic-thermodynamic assessment. Journal of Geophysical Research, Planets 112: $\mathrm{E} 07006$

Zolotov, M.Y. \& Shock, E., 2005. Formation of jarosite-bearing deposits through aqueous oxidation of pyrite at Meridiani Planum, Mars. Geophysical Research Letters 32: L21203. 